\title{
Relationships between vegetation of Macedonian pine (Pinus peuce Griseb.) and different types of soils on which it develops
}

\author{
Dejan Mandžukovski ${ }^{1}$ (i), Aco Teofilovski ${ }^{1}$, Marjan Andreevski², \\ Renata Ćušterevska ${ }^{3}$ (D), Rossen Tzonev ${ }^{4}$ (I) \& Marius Dimitrov ${ }^{5}$ (1)
}

Key words: vegetation, Macedonian pine, soil, mechanical and chemical properties, Ellenberg indicator values, Braun-Blanquet approach.

Ključne besede: vegetacija, makedonski bor, tla, mehanske in kemijske lastnosti, Ellenbergove indikatorske vrednosti, BraunBlanquetov pristop.
Corresponding author:

Dejan Mandžukovski

E-mail:

d_mandzukovski@yahoo.com

\begin{abstract}
This paper deals with relationships between vegetation of Macedonian pine (Pinus peuce) and soils developed on different parent materials on the territory of North Macedonia. We analysed the floristic composition at localities on limestone, on scree of dolomite marble and on scree of silicate. On limestone and scree of dolomite marble, rendzinas on hard limestone and dolomite have developed, and on silicate parent material brown forest soils. The vegetation was sampled according to the Braun-Blanquet approach. DCA and indicator values were used for ecological interpretation of the vegetation patterns. The mechanical and chemical properties of soil and textural classes were also processed. An evident increased presence of carbonates in the soil of scree of dolomite marble on Nidže Mountain was observed, unlike that on Shar Mountain which has formed on typical limestone. Although it is a forest community dominated by the same species, differences between the massifs, the precipitation regime, geology, differences in soil properties in relation to the appearance of carbonates and $\mathrm{pH}$ values, and other factors, result in differences in their floristic composition and are the reason for the distinction between the two groups. On silicate on Nidže Mountain, Macedonian pine forests have also developed on brown forest soils, with a different floristic composition to that of the other group on carbonate (dolomite and limestone).

Izvleček

$\mathrm{V}$ članku obravnavamo povezavo med vegetacijo makedonskega bora (Pinus peuce) in tlemi na različnih matičnih podlagah v Severni Makedoniji. Analizirali smo floristično sestavo na apnencu, na meliščih dolomitnega marmorja in silikatnih meliščih. $\mathrm{Na}$ apnencu in meliš̌čih dolomitnega marmorja so se razvile rendzine na trdnem apnencu in dolomitu, na silikatnih meliščih pa rjava gozdna tla. Vegetacijo smo vzorčili z Braun-Blanquetovo metodo. DCA in indikatorske vrednosti smo uporabili za razlago vegetacijskih vzorcev. Analizirali smo tudi mehanske in kemijske lastnosti tal ter teksturne razrede. Opazili smo očitno večjo prisotnost karbonatov v tleh na meliščih na dolomitnem marmorju na planini Nidže, za razliko od tal razvitih na tipičnem apnencu na planini Šara. Čeprav v rastlinskih združbah dominira ista vrsta, pa je vrsta sestava drugačna zaradi razlik v obeh planinah, padavinskem režimu, geologiji, talnih lastnostih v deležu karbonatov in $\mathrm{pH}$ vrednostih in drugih dejavnikih in se odraža v dveh skupinah sestojev. Na silikatu na planini Nidže so se gozdovi makedonskega bora razvili tudi na rjavih gozdnih tleh z drugačno vrstno sestavo kot $\mathrm{v}$ sestojih druge skupine na karbonatu (dolomit in apnenec).
\end{abstract}

1 Public enterprise "Nacionalni šumi”, Skopje, Republic of North Macedonia.

2 Ss. Cyril and Methodius University in Skopje, Institute of Agriculture, Skopje, Republic of North Macedonia.

3 Ss. Cyril and Methodius University in Skopje, Institute of Biology, Faculty of Natural Sciences and Mathematics, Skopje, Republic of North Macedonia.

4 Department of Ecology and Environmental Protection, Faculty of Biology, Sofia University “St. Kliment Ohridsky”, Sofia, Bulgaria.

5 Department of Dendrology, Faculty of Forestry, Forestry University, Sofia, Bulgaria. 


\section{Introduction}

The functioning and stability of ecosystems depends on the interaction of its components and the impact of the external environment associated with anthropogenic influence. In forest ecosystems, the structural and functional connection between its main components, soil and vegetation, has a special role (Rizovski, 1978; Vasilevski \& Acevski, 2004).

The correlation between vegetation and soil is an important factor of syndynamics, the further succession and pedogenesis development of ecosystems. Vegetation is important for the pedogenesis and evolution of soil, and the soil in turn affects the composition, structure and development of individual phytocoenoses. The vegetation, i.e., phytocenosis, which is an important factor in the formation of the soil structure, is of special importance for some soil types, i.e., for their formation. This is important because humus is formed after the decomposition of plant remains, which connects the mechanical elements in the aggregates. The soil composition affects the structure of the phytocoenosis, while the vegetation is important for evolution of the soil and also significantly reduces soil temperature fluctuations, protecting it from freezing in the deeper layers (Em, 1957; Vasilevski \& Acevski, 2004).

Macedonian pine (Pinus peuce Griseb.) is a tertiary relic and endemic species of the Balkan Peninsula, which A. Grisebach discovered in 1839 (locus classicus - Pelister, Baba Mountain in North Macedonia) and described in 1844 (Em, 1967; Fukarek, 1970; Džekov, 1988). This is the only pine from the subgenus Strobus native to the Balkan Peninsula (Andonoski, 1989). It occurs in some of the high mountains between the northern latitudes of $41^{\circ}$ and $43^{\circ}$. The natural range of this species consists of two areas separated by the valley of the Vardar River. The eastern part is in south-western Bulgaria and the south-western part of its distribution areal is in North Macedonia, south-western Serbia, south-eastern Montenegro, eastern Albania and north-western Greece (Andonoski, 1989; Alexandrov \& Andonovski, 2011). Pinus peuce is also listed in the global IUCN Red List of Threatened Species, with a conservation status of Near Threatened (Farjon, 2017).

From the conservation point of view, forests dominated by Macedonian pine are included in Annex I of Habitat Directive 92/43 of the European Union, with code 95A0 as high oro-Mediterranean pine forests (European Council, 1992). Macedonian pine forests were also assessed in the Red List Assessment of European Habitats (Janssen et al., 2016) as "Near Threatened", within the habitat type G 3.6 Mediterranean and Balkan subalpine Pinus heldreichii-Pinus peuce woodland.

The vegetation of Macedonian pine forests in North Macedonia has so far been only partially phytosociologi- cally researched (Em, 1965; Em \& Džekov, 1969; Horvat, 1949; Mandžukovski et al., 2009; Mandžukovski \& Acevski, 2013; Mandžukovski et al., 2015). Within this research, two associations and one community have been described to date. Two of them are in the subalpine belt: Gentiano luteae - Pinetum peuces is climazonal and Pinus peuce comm. on limestone has a relict character. Digitaly viridiflorae - Pinetum peuces in the montane and submontane belt is of more secondary occurrence. All of them are classified into the Pinion peuces alliance.

The first data related to soils under Macedonian pine forest on Pelister and Nidže Mountains. In North Macedonia this was provided by Vilarov (1965). According to this author, brown forest soils (cambisols) develop on Pelister above silicate parent material. On Nidže Mountain, the same soil type has developed on silicate parent material and rendzinas on hard limestones and dolomites on dolomite parent material.

Pedological research in Macedonian pine forests in North Macedonia was performed in the past by Popovski et al. (1969). Within this research, it was belt on Pelister, while brown forest soils (cambisols) are dominant in the montane belt. Until it was established that typical humussilicate soils were formed at high altitude and on steep slopes in the subalpine belt, there has been a lack of data about the floristic composition and soils of Macedonian pine forests on Nidže Mountain and Shar Mountain.

Studies were recently published on the Balkan Peninsular: on basophilic black pine forest in Bulgaria (Tzonev et al., 2018) and basophilic Scots pine forests in the south-eastern Alps (Rozman et al., 2020). Very important data regarding Macedonian pine was published in a paper given by Nikolov \& Dimitrov (2015).

The aim of this paper is to show the relationships between vegetation of Macedonian pine (Pinus peuce) and soils developed on different parent materials on the territory of the Republic of North Macedonia.

The floristic composition at localities of Pinus peuce communities on limestone, scree of dolomite marble and scree of silicate (glaciofluvial deposit) was analysed, together with the mechanical and chemical properties of the soils.

\section{Study area and phytogeographical circumstances}

Our research was conducted at three localities on two mountains in North Macedonia. The first is on limestone in the north-western part of the country in the locality of Plat on Shar Mountain. The second is on dolomite mar- 
ble, which is more extensive at the locality of Belo Grotlo on Nidže Mountain and the third is Macedonian pine forests on silicate bedrock at the locality Chemerikata on the top of Nidže Mountain in the southern-most part of North Macedonia near the border with Greece (Figure 1). All localities are at an elevation between 1800-2050 m.

The phytogeographical division of vegetation was adopted for North Macedonia by Rizovski (2009). The research area is situated in the Euro-Siberian-North American region and Aegean province. The researched localities are situated in two sectors:

a) the Mariovo sector, with the district of Belo Grotlo on Nidže Mountain, with relict forest of Macedonian pine (P. peuce) on scree of dolomite marble, Scots pine (Pinus sylvestris) on dolomite marble at the localities Vir and Belo Grotlo and also Macedonian pine on silicate parent material on Chemerikata;

b) the Dardanian sector, which is characterized by forests of beech, fir, spruce and Macedonian pine in the subalpine and altimontane belts, where the remains of relict forest of Macedonian pine (Pinus peuce) on limestone are dominant in the district of Upper Vardar with the subdis- trict of the River Pena. The Plat locality on Shar Mountain is situated in this sector.

According to the Biogeographical Map of Europe (Rivas-Martinez et al., 2004), the study area is classified as the Euro-Siberian biogeographical region, the ApennineBalkan province and Pindan sector.

The climate of the investigated area is mountainous, very cold and humid, with a shortened vegetation period, with cold, long and snowy winters. The annual temperature in both localities is very low $1-3{ }^{\circ} \mathrm{C}$, the sum of active temperatures is $1300^{\circ} \mathrm{C}$, with a duration of 100 days. Annual precipitation is around $1000 \mathrm{~mm}$ and begins to drop in this region. The drought index is 68, while Lang's rain factor is 210 (Filipovski et al., 1996).

\section{Material and methods}

Phytosociological investigations were performed during 2010, 2012 and 2013. The vegetation was sampled according to the Zürich-Montpellier approach (BraunBlanquet, 1964). Twelve vegetation relevés were made, each with an area between 400 and $600 \mathrm{~m}^{2}$. The taxo-

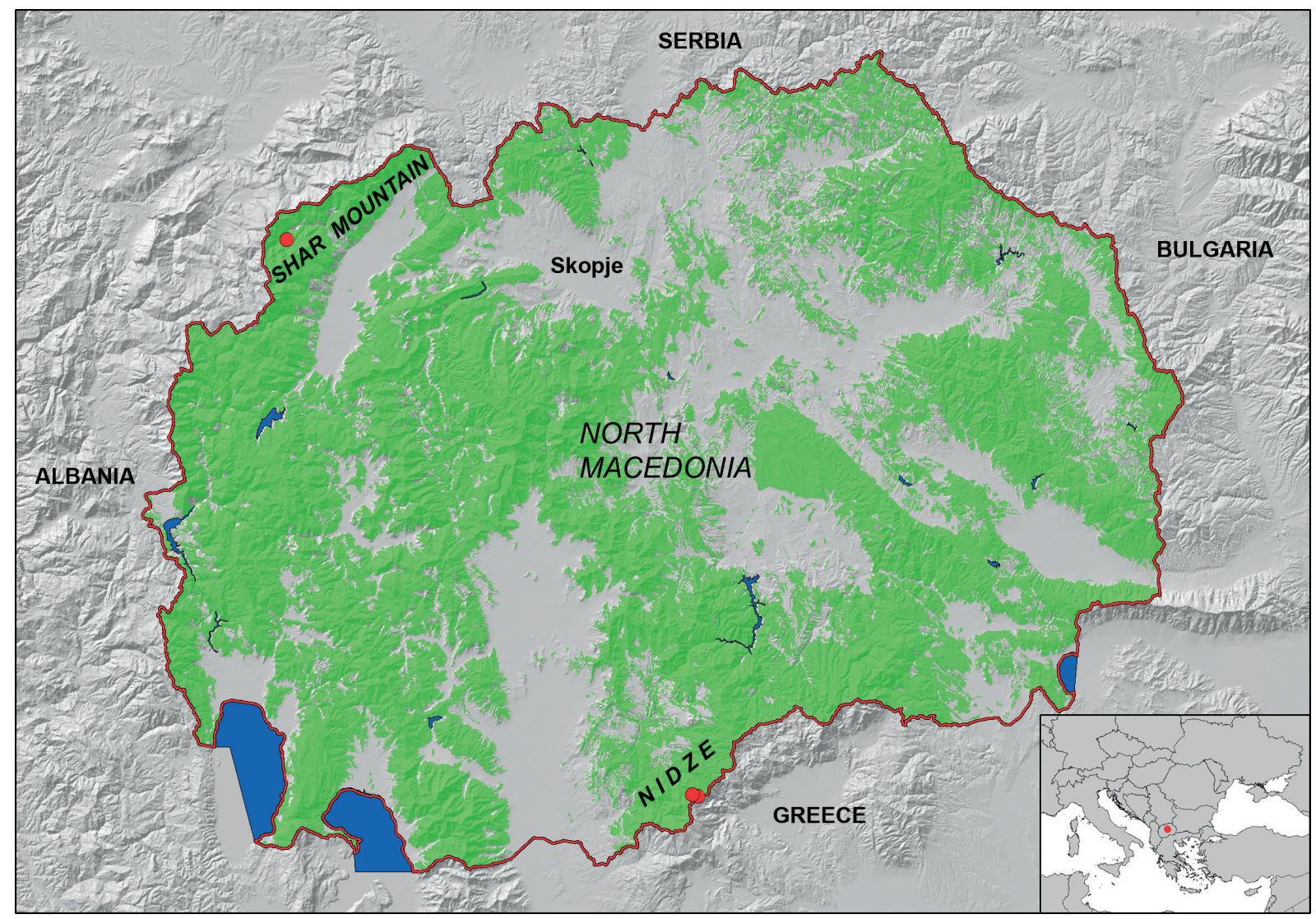

Figure 1: Two study areas on Nidže Mountain and Shar Mountain in the Republic of North Macedonia.

Slika 1: Raziskovani območji na planinah Nidže in Šara v Republiki Severni Makedoniji. 
nomic nomenclature follows Euro+Med (2006-). All relevés were stored using the TURBOVEG database (Hennekens \& Schaminée, 2001). Vegetation relevés were exported into JUICE computer software (Tichý, 2002) for further analysis, whereby an agglomerative hierarchical cluster analysis was first made in the program PC-ORD (McCune \& Mefford, 1999) for defining plant communities.

Diagnostic species of the studied syntaxa were determined by calculating fidelity using the phi $(\Phi)$ coefficient. Only species with $\Phi>0.7$ and a probability under random expectation of the observed pattern of species occurrence lower than 0.05 (Fisher's exact test) were considered diagnostic (Chytrý et al., 2002). To calculate fidelity, the number of relevés for each order or alliance was virtually standardized to equal size (Tichý \& Chytrý, 2006). Diagnostic (characteristic, differential) species are species with a distinct concentration of occurrence or abundance in a particular vegetation unit (phi coefficient above 0.7). Constant species are those with a high occurrence frequency in the given vegetation unit (frequency over 60\%) and dominant species are those with cover 25 in at least $60 \%$ of relevés (Mucina, 1993; Chytrý \& Tichý, 2003).

Detrended correspondence analysis (DCA) was performed using the $\mathrm{R}$ package 'vegan' (Oksanen et al., 2020) in JUICE software (Tichý, 2002). Floristic composition was also evaluated by Ellenberg indicator values (EIV) and climatic data. EIV were used for ecological interpretation of vegetation patterns (Ellenberg et al., 1992). Mean annual temperature (MAT) and mean annual precipitation (MAP) were generated with ClimateEU software (version 4.63) (Marchi et al., 2020) for the period from 1981 to 2009.

Soil field sampling was performed according to Filipovski et al. (1967). We sampled four (4) soil profiles in the forest vegetation of Macedonian pine, which were excavated and morphologically described in the field. Profiles 1 and 2 in Tables 2 and 3 were sampled in the same area as relevés 8 and 1 on Shar Mountain and correspond to the Pinus peuce forest community on limestone. Profile 3 is from relevé 6 and corresponds to Pinus peuce on screes of dolomite marble on Belo Grotlo on Nidže Mountain. Profile 4 was sampled in the area of relevé 11 in Table 1 and 2, on silicate parent material (glacio fluvial deposit) at the locality Chemerikata on Nidže Mountain.

Soil samples were thereafter air dried and taken to the laboratory at the Department of Soil Science -Institute of Agriculture, Ss. Cyril and Methodius University in Skopje for analysis of mechanical composition and chemical properties.

The laboratory analyses were performed according to standard adopted methods as follows:
- The mechanical composition of the soil was determined according to the international A-method (JPDZ, 1971), and peptization was carried out with $0.1 \mathrm{M}$ sodium pyrophosphate. Fractioning of the mechanical elements was performed according to the international classification, and the classification of the soil in texture classes was according to Scheffer \& Schachtschabel (Filipovski, 1984);

- The content of calcium-carbonate was determined using Scheibler's calcimeter (JPDZ, 1966);

- The $\mathrm{pH}$ (reaction) of the soil solution was determined with a glass electrode in a water suspension and in an NKCI suspension (JPDZ, 1966);

- Total $\mathrm{N}$ was determined by the Kjeldahl micromethod (JPDZ, 1966);

- Easily available forms of $\mathrm{P}_{2} \mathrm{O}_{5}$ and $\mathrm{K}_{2} \mathrm{O}$ were determined according to Manojlović et al. (1969);

- The content of humus was determined on the basis of total carbon by the Tjurin method modified by Simakov (Orlov \& Grišina, 1981);

- The sum of exchangeable bases (SEB) and acid cations (T-S) was determined by the Kappen method (JPDZ, 1966). The cation exchange capacity (CEC) and the degree of base saturation of soil (V) was calculated.

\section{Results and discussion}

\section{Vegetation analysis}

Twelve relevés were sampled in the Macedonian pine forests. Cluster analysis (Figure 2) resulted in three ecologically meaningful relevé groups. The first group comprises relevés 1-7 from Nidže Mountain, appearing on dolomite marble (locality Belo Grotlo). The second group, (relevés 8, 9 and 10) corresponds to a Pinus peuce forest community on limestone at the Plat locality on Shar Mountain, and the third group (relevés 11 and 12) represents Pinus peuce forests on silicate that have developed on Nidže Mountaint at the Chemerikata locality. The localities are shown in Figure 1.

The analytical table (Table 4) shows the characteristics of floristic composition within the obtained groups on the basis of diagnostic and constant species. The group thriving on dolomite marble on Nidže Mountain forms Cluster 1 (locality Belo Grotlo) and is characterised by:

Diagnostic species: Armeria canescens, Asperula aristata, Aurinia rupestris, Bupleurum falcatum, Carex kitaibeliana, Cerastium decalvans, Edraianthus graminifolius, Festuca hirtovaginata, Festuca kozanensis, Galium oreophilum, Polygala major, Saxifraga sempervivum, Sedum ochroleucum, Thymus boissieri 


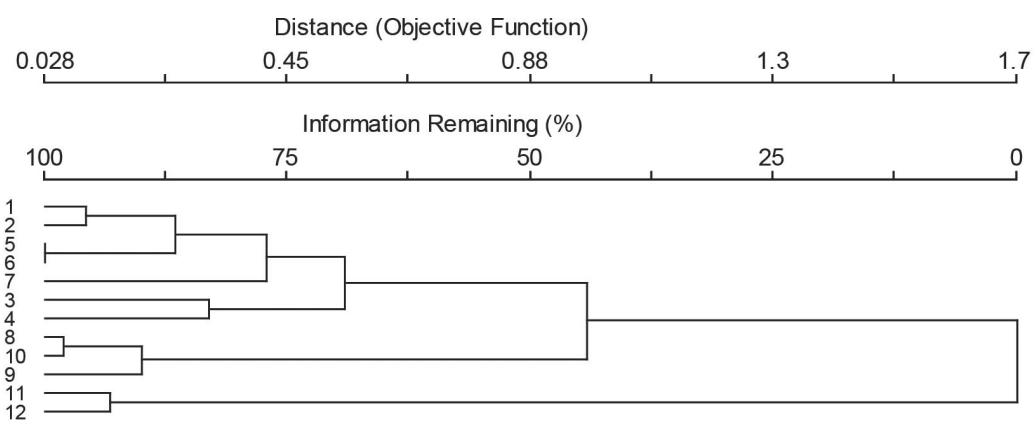

Figure 2: Dendrogram of analysed relevés 1.7 obtained by the square root transformation of cover values in percentages, the Beta flexible $(\beta=-0.25)$ method and group linkage with the relative Sørensen index. The dendrogram shows similarities between relevés. The numbers of the relevés correspond to those in Table 4.

Slika 2: Dendrogram analiziranih vegetacijskih popisov narejen $s$ korenjenem pokrovnih vrednosti v odstotkih, Beta fleksibilno metodo $(\beta=-0.25)$ in povprečno metodo z relativnim Sørensenovim indeksom. Dendrogram prikazuje podobnost med popisi. Številke popisov so enake kot v Tabeli 4 .

Constant species: Abies borisii-regisx, Arctostaphylos uvaursi, Iberis sempervirens, Juniperus communis subsp. alpina, Vaccinium myrtillus; Cardamine glauca, Galium anisophyllon, Luzula sylvatica, Pinus peuce, Ranunculus montanus, Saxifraga scardica, Sesleria tenerrima

Dominant species: Pinus peuce

The second group (Cluster 2), which includes relevés over limestone from Plat on Shar Mountain is distinguished by:

Diagnostic species: Picea abies; Lonicera xylosteum; Rubus idaeus; Alchemilla velebitica, Anemone narcisiflora, Avenella flexuosa, Bromopsis riparia, Bupleurum falcatum subsp. cernuum, Carex sempervirens, Crepis viscidula, Galium mollugo, Gentiana punctata, Geranium sylvaticum, Hieracium sericophyllum, Hypericum richeri subsp. grisebachii, Hypochaeris maculata, Lonicera alpigena subsp. formanekiana, Melampyrum sylvaticum, Myosotis suaveolens, Pedicularis verticillata, Persicaria vivipara, Phyteuma orbiculare, Pinguicula balcanica, Rumex acetosa, Saxifraga rotundifolia, Silene pusilla subsp. albanica, Soldanella pindicola, Trollius europaeus

Constant species: Sorbus aucuparia; Daphne mezereum; Dryas octopetala, Helianthemum nummularium, Juniperus communis subsp. alpina, Vaccinium myrtillus; Campanula rotundifolia, Cardamine glauca, Dianthus integer subsp. minutiflorus, Galium anisophyllon, Lilium albanicum, Linum capitatuma, Luzula sylvatica, Pinus peuce, Ranunculus montanus

Dominant species: Pinus peuce

The third group (Cluster 3) on silicate bedrock developed on silicate material at Chemerikata on Nidže Mountain:

Diagnostic species: Athyrium filix-femina, Clinopodium grandiflorum, Doronicum austriacum, Dryopteris filixmas, Elymus caninus, Galium odoratum, Lactuca muralis, Poa pratensis, Primulla veris subsp. columnae, Rubus hirtus, Sanicula europaea, Stellaria nemorum subsp. nemorum, Veratrum album, Viola reichenbachiana
Constant species: Abies borisii-regis; Luzula sylvatica, Pinus peuce

Dominant species: Pinus peuce

The DCA diagram (Figure 3) reveals that there are two main gradients. The first axis represents the division between relevés on carbonate (limestone and dolomite marble) and on silicate and corresponds to passively projected Ellenberg indicator values for temperature, continentality, light and nutrients. The second axis repre-

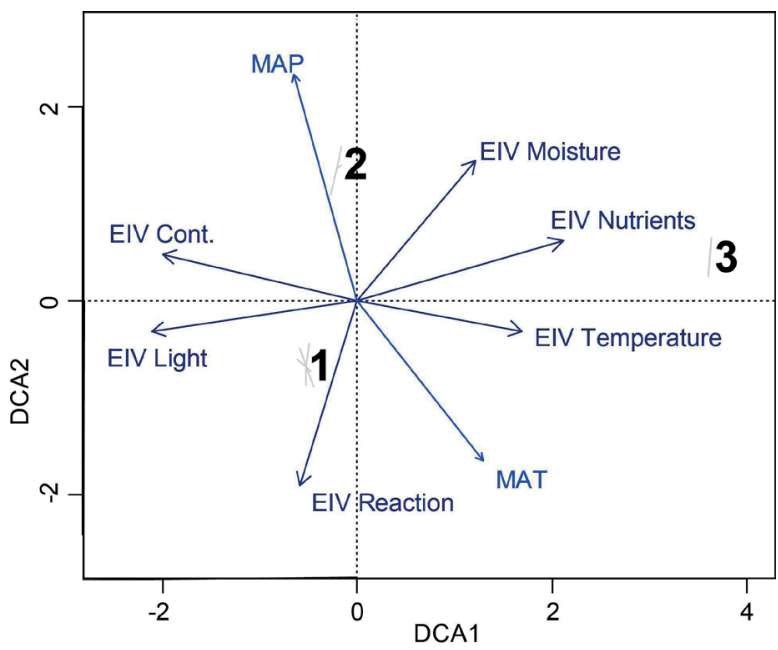

Figure 3: Ordination diagram of Detrended Correspondence Analysis (DCA) of the three studied Pinus peuce communities, with Ellenberg indicator values, mean annual temperature (MAT) and mean annual precipitation (MAP) passively projected. Eigenvalues for the first two axes are 0.631 and 0.429 , respectively. $1-P$. peuce comm. on dolomite marble from Nidže Mountain (Belo Grotlo); $2-P$. peuce comm. on limestone on Shar Mountaint (Plat); $3-P$. peuce comm. on silicate from Nidže Mountain; see Figure 2.

Slika 3: Ordinacijski diagram kanonične analize z odstranjenim trendom (DCA) treh združb z vrsto Pinus peuce z pasivno projiciranimi Ellenbergovimi indikatorskimi vrednostmi, povprečno letno temperaturo (MAT) in povprečnimi letnimi padavinami (MAP). Lastni vrednosti za prvi dve osi sta 0,631 in 0,429. 1 - združba z P. peuce na dolomitnem marmorju s planine Nidže (Belo Grotlo); 2 - združba z P. peuce na apnencu Šara (Plat); 3 - združba z P. peuce na silikatu s planine Nidže; glej Sliko 2. 
sents (macro)ecological conditions, such as mean annual temperature and precipitation. There is higher precipitation on Shar Mountain due to the inland location of the mountain massif, which is exposed to precipitation of up to $1100(1200) \mathrm{mm}$ and a higher annual temperature on Nidže Mountain due to the location of the mountain in the central-southern parts of the Balkans. The Ellenberg value moisture corresponds to both axes, since the silicate bedrock contains more moisture, on the one hand, and Shar Mountain on limestone gets more precipitation, on the other.

The floristic composition (Figure 3, Table 4) shows that a large proportion of species from mesophilous forests, Sanicula europea, Stellaria nemorum, Oxalis acetosella, appear in humidity rich sites on silicate bedrock at the Chemerikata locality on Nidže Mountain (Em, 1975; Matevski et al., 2011). The Shar Mountain stands are characterized by calciphilous alpine grassland species that appear in a more humid climate, such as: Carex sempervirens, Ranunculus montanus, Trolius europaeus (Micevski, 1994), as well as other cool adapted species of humid habitats, such as Hypericum richeri subsp. grisebachii, Picea abies, Geranium sylvaticum (Em, 1984). On Nidže Mountain, in Macedonian pine forest on dolomite marble, in drier macroclimatic conditions, a number of elements of dry, oromediterranean grasslands can be found, such as Bupleurum falcatum, Festuca kozanensis, Daphne oleoides, Dianthus integer (Ćušterevska, 2015; Matevski et al., 2018). In addition, preliminary, vegetation communi- ties that are processed in this article can be classified into the Pinion peuces alliance.

\section{Soil analysis}

On the basis of soil analysis, we obtained three (3) soil types. $\mathrm{N}^{\text {os }} 1,2,3$ are described as rendzina on hard limestones and dolomites formed under vegetation types of groups 1 and 2, appearing over carbonate limestone (according to the WRB classification rendzic leptosol). Profile 4 was sampled in the area of relevé 11 in Tables 1 and 2 on silicate parent material (glacio-fluvial deposit) at the Chemerikata locality on Nidže Mountain. It is brown forest soil (according to the WRB classification cambisol) in the Pinus peuce comm. on silicate.

From the data obtained in the mechanical laboratory presented in Table 2, it can be concluded that the fine earth (fractions $<2 \mathrm{~mm}$ ) of the examined soils is characterized by a favourable mechanical composition, but the skeletal content (fractions $>2 \mathrm{~mm}$ ) is high. Because of this mechanical composition, the physical properties of the soil are deteriorated, i.e., the water permeability of the soil is high and the water retention is low.

The profiles of rendzina on hard limestones and dolomites (profiles 1, 2 and 3) have deteriorated physical properties due to the shallowness of the profile and the extremely high permeability of the substrate (limestones and scree of dolomite marble).

Table 1: Textural classes according to the classification of Scheffer and Schachtschabel in soil horizons (fine sandy loam, loamy fine sand, loam, clay loam) and some soil-forming factors of soil in the field (occurrence of outcrops and stoniness in \%) in Pinus peuce forest communities on Shar Mountain and Nidže Mountain.

Tabela 1: Teksturni razredi po klasifikaciji Scheffer in Schachtschabel v talnih horizontih (fina peščena ilovica, fin ilovnat pesek, ilovica, glinasta ilovica) in nekateri tlotvorni dejavniki (skalovitost in površinska kamenitost v \%) v gozdnih združbah z vrsto Pinus peuce na planinah Šara in Nidže.

\begin{tabular}{|c|c|c|c|c|c|c|c|c|c|c|c|}
\hline $\begin{array}{l}\text { Profile } \\
\text { No. }\end{array}$ & Soil type & Horizon & Depth & Vegetation & $\begin{array}{l}\text { Altitude } \\
\text { m }\end{array}$ & $\begin{array}{c}\text { Parent } \\
\text { material }\end{array}$ & Exposure & $\begin{array}{l}\text { Inclination } \\
\%\end{array}$ & $\begin{array}{c}\text { Occurrence } \\
\text { of outcrops } \\
\%\end{array}$ & $\begin{array}{l}\text { Stoniness } \\
\%\end{array}$ & $\begin{array}{l}\text { Textural classes } \\
\text { according to Scheffer } \\
\text { \& Schachtschabel }\end{array}$ \\
\hline 1 & $\begin{array}{l}\text { rendzinas on } \\
\text { hard limestone } \\
\text { and dolomite }\end{array}$ & $\mathrm{O}$ & $0-19$ & $\begin{array}{l}\text { P. peuce } \\
\text { comm. on } \\
\text { limestone }\end{array}$ & 2073 & $\begin{array}{c}\text { plate } \\
\text { limestone }\end{array}$ & North & $40-50$ & 0 & 0 & Sandy clay loam \\
\hline 2 & $\begin{array}{l}\text { rendzinas on } \\
\text { hard limestone } \\
\text { and dolomite }\end{array}$ & $\begin{array}{l}\mathrm{O} \\
\mathrm{A}\end{array}$ & $\begin{array}{c}3-10 \\
10-25\end{array}$ & $\begin{array}{l}\text { P. peuce } \\
\text { comm. on } \\
\text { limestone }\end{array}$ & 2094 & $\begin{array}{l}\text { plate } \\
\text { limestone }\end{array}$ & North & $40-50$ & $1-3$ & 0 & $\begin{array}{l}\text { Clay loam } \\
\text { Fine sandy loam }\end{array}$ \\
\hline 3 & $\begin{array}{l}\text { rendzinas on } \\
\text { hard limestone } \\
\text { and dolomite }\end{array}$ & $\begin{array}{l}\mathrm{O} \\
\mathrm{A} \\
\mathrm{A}\end{array}$ & $\begin{array}{c}0-12 \\
12-41 \\
41-71\end{array}$ & $\begin{array}{c}\text { P. peuce } \\
\text { comm. on } \\
\text { scree of } \\
\text { dolomite } \\
\text { marble }\end{array}$ & 2037 & $\begin{array}{l}\text { scree of } \\
\text { dolomite } \\
\text { marble }\end{array}$ & North & $40-50$ & $3-5$ & $3-5$ & $\begin{array}{l}\text { Loam } \\
\text { Fine sandy loam }\end{array}$ \\
\hline 4 & $\begin{array}{l}\text { brown } \\
\text { forest soils - } \\
\text { (cambisols) }\end{array}$ & $\begin{array}{c}\mathrm{O} \\
\mathrm{A} \\
(\mathrm{B})_{\mathrm{v}} \\
(\mathrm{B})_{\mathrm{v} C}\end{array}$ & $\begin{array}{c}0-9 \\
9-40 \\
40-79 \\
79-122\end{array}$ & $\begin{array}{l}\text { P. peuce } \\
\text { comm. on } \\
\text { silicate }\end{array}$ & 1790 & $\begin{array}{l}\text { Glacio } \\
\text { fluvial } \\
\text { deposit }\end{array}$ & North & $30-40$ & 0 & 0 & $\begin{array}{l}\text { Fine sandy loam } \\
\text { Fine sandy loam } \\
\text { Loamy fine sand }\end{array}$ \\
\hline
\end{tabular}




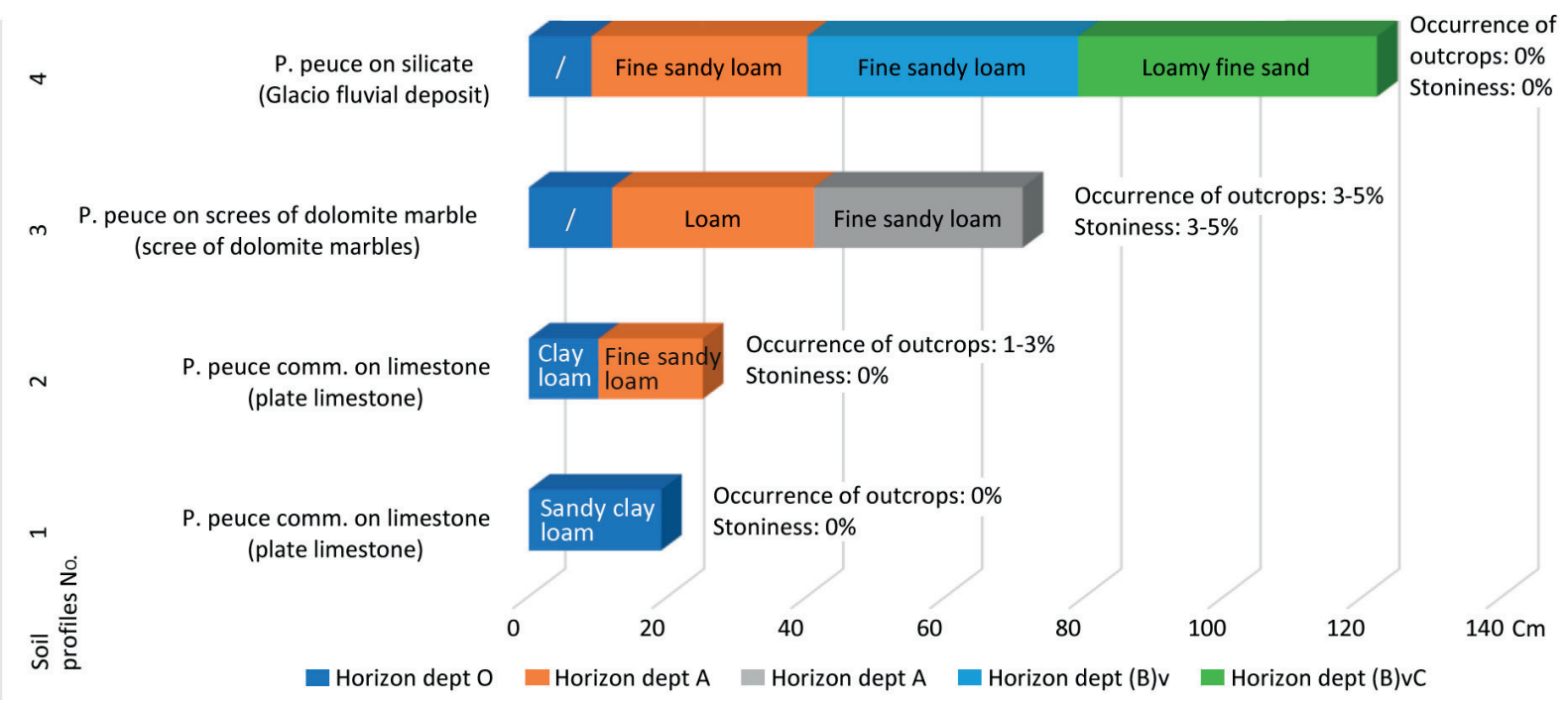

Figure 4: Textural classes according to the classification of Scheffer and Schachtschabel in soil horizons (fine sandy loam, loamy fine sand, loam, clay loam) and some soil-forming factors of soil in the field (occurrence of outcrops and stoniness in \%) in Pinus peuce forest communities on Shar Mountain and Nidže Mountain.

Figure 4: Teksturni razredi po klasifikaciji Scheffer in Schachtschabel v talnih horizontih (fina peščena ilovica, fin ilovnat pesek, ilovica, glinasta ilovica) in nekateri tlotvorni dejavniki (skalovitost in površinska kamenitost v \%) v gozdnih združbah z vrsto Pinus peuce na planinah Šara in Nidže.

Table 2: Characteristics of the mechanical composition of soil samples (in \% of fine earth). Localities: 1, 2 limestone on Shar Mountain, 3 dolomite marble on Nidže Mountain, 4 silicate on Nidže Mountain.

Tabela 2: Značilnosti mehanske sestave talnih vzrocev (v \% finih delcev). Lokacije: 1, 2 apnenenec na planini Šara, 3 dolomitni marmor na planini Nidže, 4 silikat na planini Nidže.

\begin{tabular}{|c|c|c|c|c|c|c|c|c|c|}
\hline $\begin{array}{l}\text { Number } \\
\text { of samples }\end{array}$ & Horizon & $\begin{array}{l}\text { Depth } \\
\text { in } \mathrm{cm} \\
\end{array}$ & $\begin{array}{l}\text { Skeleton } \\
>2 \mathrm{~mm}\end{array}$ & $\begin{array}{l}\text { Coarse sand } \\
0.2-2 \mathrm{~mm} \\
\end{array}$ & Fine sand & $\begin{array}{l}\text { Coarse + } \\
\text { fine sand }\end{array}$ & $\begin{array}{c}\text { Silt } \\
0.002-0,02 \mathrm{~mm} \\
\end{array}$ & $\begin{array}{c}\text { Clay } \\
<0.002 \mathrm{~mm} \\
\end{array}$ & Silt+Clay \\
\hline 1 & $\mathrm{O}$ & $0-19$ & 12.74 & 5 & 62 & 67 & 17.3 & 15.7 & 33 \\
\hline \multirow{2}{*}{2} & $\mathrm{O}$ & $3-10$ & 4.63 & 3.6 & 56.9 & 60.5 & 20.3 & 19.2 & 39.5 \\
\hline & A & $10-25$ & 42.34 & 11 & 47.5 & 58.5 & 29.6 & 11.9 & 41.5 \\
\hline \multirow{3}{*}{3} & $\mathrm{O}$ & $0-12$ & 1 & I & 1 & 1 & 1 & 1 & 1 \\
\hline & A & $12-41$ & 7.47 & 0.1 & 63.3 & 63.4 & 27.6 & 9 & 36.6 \\
\hline & $\mathrm{A}$ & $41-71$ & 21 & 1.2 & 77.7 & 78.9 & 12.5 & 8.6 & 21.1 \\
\hline \multirow{4}{*}{4} & $\mathrm{O}$ & $0-9$ & I & 1 & 1 & 1 & 1 & 1 & 1 \\
\hline & A & $9-40$ & 25.2 & 16 & 53.9 & 69.9 & 15.3 & 14.8 & 30.1 \\
\hline & $(\mathrm{B})_{\mathrm{V}}$ & $40-79$ & 32.93 & 16.2 & 58.3 & 74.5 & 13.4 & 12.1 & 25.5 \\
\hline & $(\mathrm{B}) \mathrm{vC}$ & $79-122$ & 46.9 & 19.3 & 66 & 85.3 & 9.4 & 5.3 & 14.7 \\
\hline
\end{tabular}

For some part of horizon $\mathrm{O}$, no samples were taken for laboratory analysis in some profiles in the field (Table 2, Table 3), because in these cases horizon $\mathrm{O}$ consisted only of undecomposed needles.

The decay process of needles is slower for coniferous species due to the accumulation of organic matter, accompanied by adverse climatic influences. However, due to the construction of the profiles, all the horizons are shown here, even though there are no values anywhere.

The soil samples are non-carbonate (Table 3) except for the soil samples from dolomite marble from Nidže
Mountain, which are very carbonate. Despite the high content of carbonates in this profile, the reaction of the soil is not high. Similar $\mathrm{pH}$ values and carbonate contents for rendzina on hard limestone and dolomite formed on dolomite from Nidže Mountain were already presented by Vilarov (1965). For soils formed on screes on dolomite and dolomite marble, it is characteristic that the carbonates are found in coarser fractions (coarse + fine sand) and the influence of the soil reaction is therefore small. The reaction of the soil in water in the two soil samples from profile 3 is neutral. Acidophilic species such as Vaccinium 
Table 3: Characteristics of soil samples for chemical properties. Localities: 1, 2 limestone on Shar Mountain, 3 dolomite marble on Nidže Mountain, silicate on Nidže Mountain ( $\mathrm{S}$ - sum of bases, T-S - adsorbed acid ions, T - adsorption capacity of cations, $\mathrm{V}$ - degree of saturation with base cations).

Tabela 3: Značilnosti talnih vzorcev. Lokacije 1, 2 apnenenc na planini Šara, 3 dolomitni marmor na planini Nidže, 4 silikat na planini Nidže ( $\mathrm{S}$ - vsota baz, T-S - adsorbirani kisli ioni, T - adsorpcijska kapaciteta kationov, V - stopnja saturacije z bazičnimi kationi).

\begin{tabular}{|c|c|c|c|c|c|c|c|c|c|c|c|c|c|}
\hline \multirow{2}{*}{$\begin{array}{c}\text { Number } \\
\text { of } \\
\text { samples }\end{array}$} & \multirow{2}{*}{ Horizon } & \multirow[t]{2}{*}{$\begin{array}{l}\text { Depth } \\
\text { in } \mathrm{cm}\end{array}$} & \multirow[t]{2}{*}{$\begin{array}{c}\mathrm{CaCO}_{3} \\
\%\end{array}$} & \multirow[t]{2}{*}{$\begin{array}{c}\text { Humus } \\
\%\end{array}$} & \multirow[t]{2}{*}{$\begin{array}{l}\text { Total } \\
\mathrm{N} \%\end{array}$} & \multirow{2}{*}{\multicolumn{2}{|c|}{${ }_{\mathrm{m}}^{\mathrm{pH}}$}} & \multicolumn{2}{|c|}{$\begin{array}{l}\text { Easily available } \\
\mathrm{mg} / 100 \mathrm{~g} \text { soil }\end{array}$} & & T-S & \multirow[t]{2}{*}{$\mathrm{T}$} & \multirow{2}{*}{$\begin{array}{l}\mathrm{V} \\
\%\end{array}$} \\
\hline & & & & & & & & $\mathrm{P}_{2} \mathrm{O}_{5}$ & $\mathrm{~K}_{2} \mathrm{O}$ & $\mathrm{cm}$ & (+) kg- & & \\
\hline 1 & $\mathrm{O}$ & $0-19$ & 0 & 26.38 & 0.81 & 5.25 & 4,5 & 6.08 & 26.99 & 35.81 & 29.25 & 65.06 & 55.04 \\
\hline \multirow{2}{*}{2} & $\mathrm{O}$ & $3-10$ & 0 & 45.78 & 1.32 & 5.55 & 5,05 & 14.44 & 41.74 & 51.8 & 23.07 & 74.87 & 69.19 \\
\hline & A & $10-25$ & 0 & 8.59 & 0.33 & 5.5 & 4,85 & 1.14 & 9 & 17.2 & 20.66 & 37.86 & 45.43 \\
\hline \multirow{3}{*}{3} & $\mathrm{O}$ & $0-12$ & I & I & I & 1 & I & I & I & I & I & I & I \\
\hline & A & $12-41$ & 22.78 & 22.13 & 0.76 & 6.8 & 6,2 & 2.66 & 33.46 & I & I & I & I \\
\hline & A & $41-71$ & 51.79 & 4.86 & 0.21 & 7.25 & 6,9 & 1.33 & 15.83 & 1 & 1 & 1 & 1 \\
\hline \multirow{4}{*}{4} & $\mathrm{O}$ & $0-9$ & 1 & I & I & I & 1 & 1 & I & 1 & 1 & 1 & I \\
\hline & A & $9-40$ & 0 & 4.35 & 0.19 & 4.8 & 3.9 & 7.98 & 16.19 & 6.2 & 23.07 & 29.27 & 21.18 \\
\hline & $(B) v$ & $40-79$ & 0 & 1.79 & 0.1 & 5 & 4 & 2.28 & 8.64 & 2.6 & 17.55 & 20.15 & 12.9 \\
\hline & (B) $\mathrm{vC}$ & $79-122$ & 0 & 1.43 & 0.08 & 5 & 4.2 & 1.71 & 5.4 & 1.7 & 12.35 & 14.05 & 12.1 \\
\hline
\end{tabular}

myrtillus and Luzula sylvatica therefore appear in the relevés from profiles 1,2 and 3 . Other important characteristics of soils formed on dolomite and dolomite marble are an increased presence of $\mathrm{Mg}$ ions in the soil solution and the adsorption complex of the soil and, in some cases, even a higher presence of this ion compared to the $\mathrm{Ca}$ ion. This is because the parent material of dolomite marble has a high content of the $\mathrm{Mg}$ ion. Unlike the cases of dolomite and dolomite marble, in the adsorption complex and soil solution of soils formed on hard limestone and calcite marble, the Ca ion is dominant. In fact, the Ca ion is dominant in all soils in the Republic of North Macedonia, except in soils formed on dolomite, dolomite marble and serpentine (Filipovski, 1996).
Profiles 1 and 2 are formed on hard limestone. A characteristic of rendzina on hard limestone and dolomite is that the solum (soil) is non-carbonated, despite the fact that the rock is built in some cases of over $99 \% \mathrm{CaCO}_{3}$ (Filipovski, 1996). In fact, the solum in these soils is formed by the silicate residue that is embedded in the limestone rock and is released by dissolving the limestone. This process is very slow and, in some cases, it takes from 8,000 to 10,000 years for the formation of $1 \mathrm{~cm}$ of soil (Filipovski, 1984). According to the American classification (Filipovski, 1984), the reaction of soil to water in profiles 1 and 2 is strongly acidic. Another feature of rendzina on hard limestone and dolomite is that the

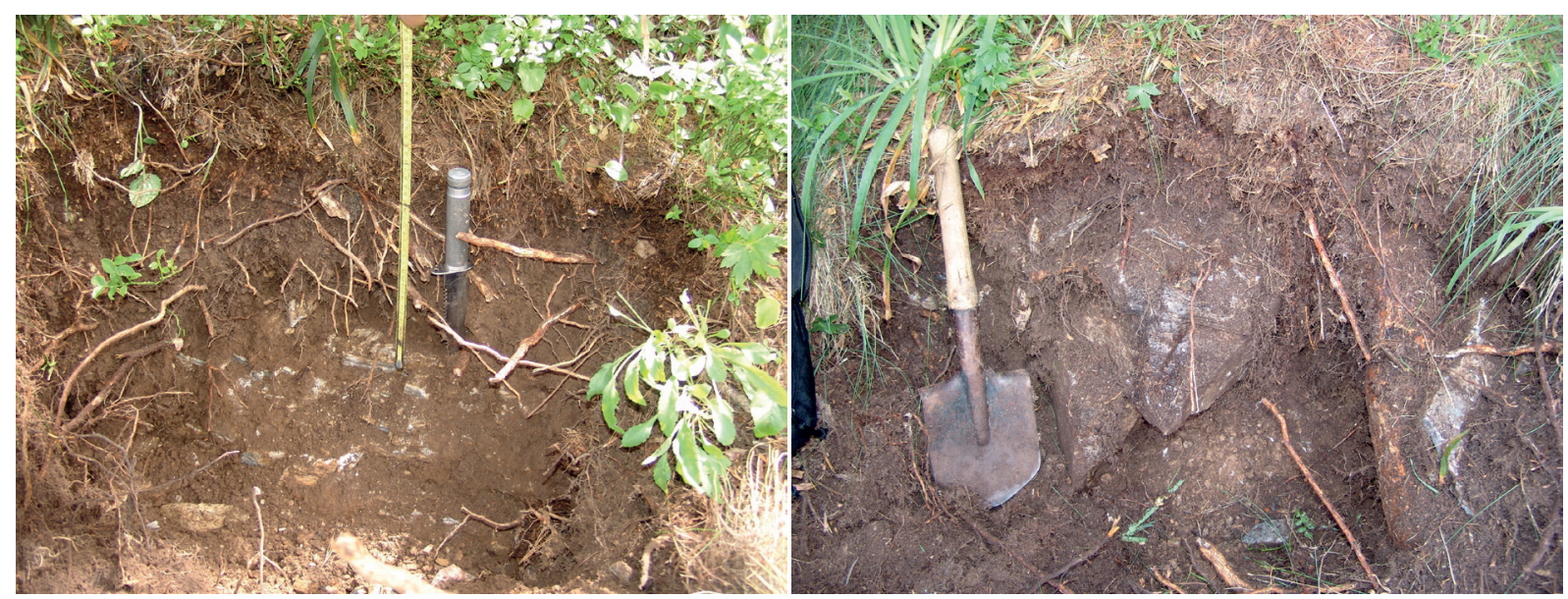

Figure 5: Profiles 1 and 2 Plat - Shar Mountain rendzinas on hard limestones and dolomites on plate limestone. Slika 5: Talna profila 1 in 2 Plat - planina Šara rendzina na trdih apnencih in dolomitih na ploščatem apnencu. 


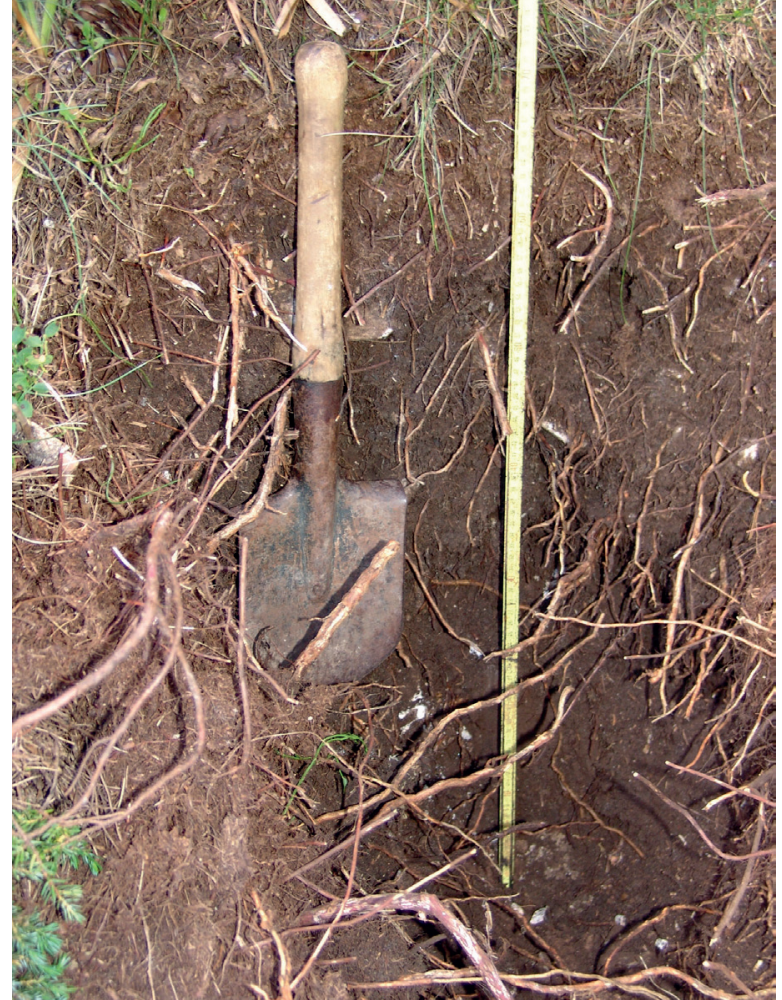

Figure 6: Profile 3 Belo Grotlo - Nidže Mt. rendzinas on hard limestone and dolomite on dolomite marble.

Slika 6: Talni profil 3 Belo Grotlo - planina Nidže rendizna na trdnem apnencu in dolomitu na dolomitnem marmorju.

depth of the solum varies over very short distances, i.e., the contact of the root with the carbonate limestone wall is greater or less. In shallower soils, the root is in stronger contact with the limestone rock and in deeper soils it is less so. It is therefore possible for both acidophilous and basophilous species to be present within short distances.

On the other hand, the forests of Pinus peuce comm. on silicate in group 3, which develop at Chemerikata on Nidže Mountain on silicate parent material and cambisols, show a greater correlation with nutrients, if we take into account that the vegetation develops on deep soils with an active starting horizon. Due to the great depth of the solum of profile 4 (brown forest soil) and the character of the parent substrate (glaciofluvial deposit) the plants can draw water and nutrients from a larger volume of soil, i.e., it is a more favourable habitat for plant development compared to rendzina on hard limestones and dolomites.

The situation in relation to the chemical properties is clearest in profile 4 . The soil is non-carbonate, with low $\mathrm{pH}$ values, throughout the whole solum. The reaction of the soil is very strongly acidic. These are also the most favourable habitats for Macedonian pine, mainly due to

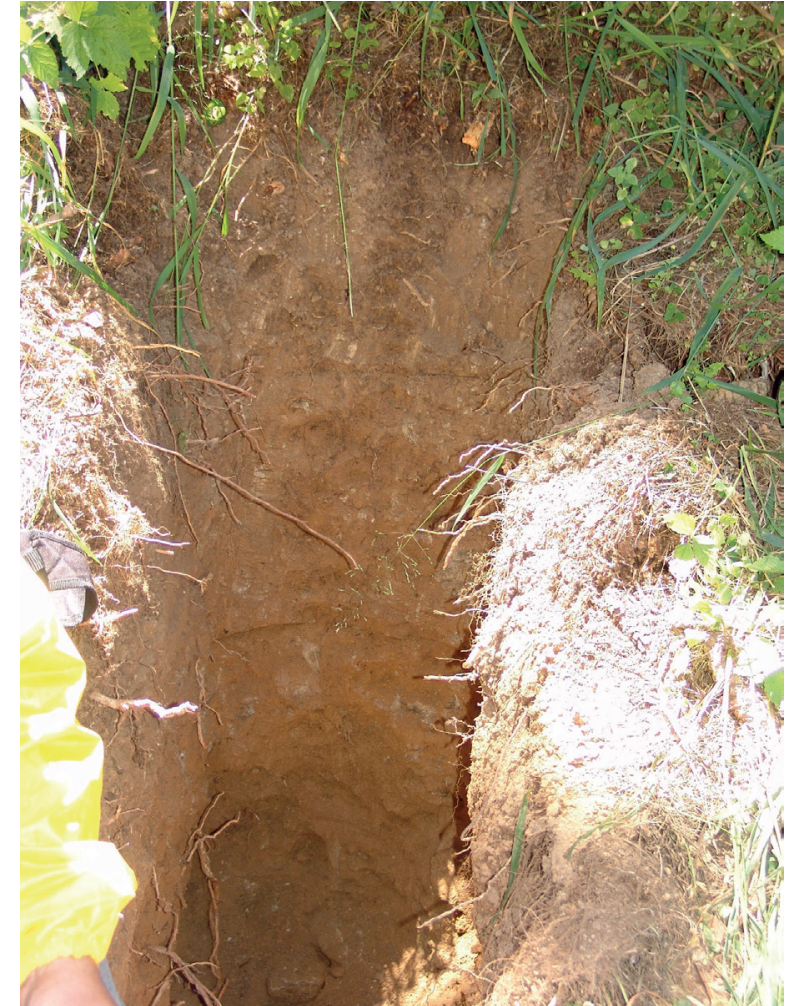

Figure 7: Profile 4 Chemerikata - Nidže Mt. brown forest soils (cambisols) on Glacio fluvial deposit.

Slika 7: Talni profil 4 Chemerikata - planina Nidže rjava gozdna tla (kambisol) na glacio-fluvialnem depozitu.

the deep solum and the physiologically active profile, i.e., the roots of the Macedonian pine penetrate deeper than the solum (Horizon C / R, glaciofluvial deposit). Similar data were provided by Popovski et al. (1969) for Pelister, and Vilarov (1965) for Nidže and Pelister.

The humus content in the examined soils on limestone and dolomite marble is high, compared to soil developed on silicate parent material. According to the classification of Gračanin (JPDZ, 1966) profile 1, hor. O of profile 2 and horizon $\mathrm{A}$ of profile 3 are very strongly humorous (over 10\% humus), hor. A of profile 2 is strongly humorous $(5-10 \%$ humus), and the second depth $(41-71 \mathrm{~cm})$ of profile 3 and hor. A of profile 4 are quite humorous (from 3-5\%) and hor. (B) v and (B) vC of profile 4 weakly humorous (from 1-3\% humus).

Because most of the total nitrogen is in organic form, due to the high content of humus, the content of total nitrogen is high. Profiles 1 and 2 and the first depth of profile 3 are very richly provided with total nitrogen, the second depth of prof. 3 is also well supplied, prof. 4 hor. $\mathrm{A}$ and (B)v is well supplied and hor. (B) $\mathrm{vC}$ is intermediately provided. Urtica dioica also appears on Shar Mountain (profile 1 and 2) because of this. 
According to the AL method used (Manojlović et al., 1969), all soil samples are poorly supplied with easily available phosphorus, except for hor. O of profile 2, which is moderately provided. According to the same method, profile 1, hor. O of profile 2 and hor. A of profile 3 are well supplied (over $20 \mathrm{mg} / 100 \mathrm{~g}$ soil) with easily available potassium (below $10 \mathrm{mg} \mathrm{mg} / 100 \mathrm{~g}$ soil), the second depth of profile 3 and hor. A of profile 4 are moderately supplied (from 10-20 mg/ 100g soil) and the rest are poorly supplied.

The adsorption capacity of cations $(\mathrm{T})$ is high especially in profiles 1, 2 and hor. A of profile 4, which is mainly due to the high content of humus.

From the data on the degree of base saturation $(\mathrm{V})$ and $\mathrm{pH}$ values, it can be concluded that acidification is advanced. Acidification is most advanced in profile 4, which is seen from the lowest $\mathrm{pH}$ values and the lowest values for the degree of saturation with base cations. Due to the presence of $\mathrm{CaCO}_{3}$ in profile 3 , the resulting organic and inorganic acids are neutralized and there is no major acidification of the soil solution.

\section{Relation to vegetation, soil and climate}

Vegetation is of great importance for all pedogenetic processes and soil properties. It affects, together with other pedogenetic factors, especially climate, and its role is most important in the accumulation of organic matter and biogenic elements (Filipovski et al., 1996).

Limestone terrains are water permeable and fairly dry, and they are not usually suitable for the development of Macedonian pine, because it is a semi-sciophyte species.
Basically, the appearance of Macedonian pine on the limestone slopes of Shar Mountain and on the screes on dolomite marble of Nidže Mountain is common for the high subalpine belt and shady aspect (Janković, 1960; Mandžukovski et al., 2015).

However, if limestone and dolomite terrains are moderately steep and with an accumulated soil layer in the upper part of the soils, then it retains soil moisture and, in conditions of increased atmospheric precipitation, there is the possibility of the development of Macedonian pine.

According to our observations at a location on Greek territory, which is in the immediate vicinity of Belo Grotlo on Nidže mountain but has an eastern exposure, there is a fairly large slope consisting of dolomitic marble with a slight inclination. At this site, although exposed to a warmer aspect, the Macedonian pine has formed a younger population, since it has accumulated a soil layer that keeps the soil moist for an extended period.

The snow also remains on both mountains until the beginning of June, which of course contributes to the continuous wetting of the substrate. Fog is very frequent in these areas.

It should be added that the impact of the mountain climate, as well as the amount of precipitation, which is around $1000 \mathrm{~mm}$ and more on Nidže Mountain, and on Shar Mountain up to 1100 (1200) mm, influences the edapho-ecological factors for the development of Macedonian pine on carbonate terrains, which has also been observed by other authors (Košanin, 1912; Košanin, 1925; Radulović, 1939; Janković, 1960; Janković, 1962; Janković, 1970; Georgiev, 1970; Stevanović et al., 1995; Bucalo et al., 2012).

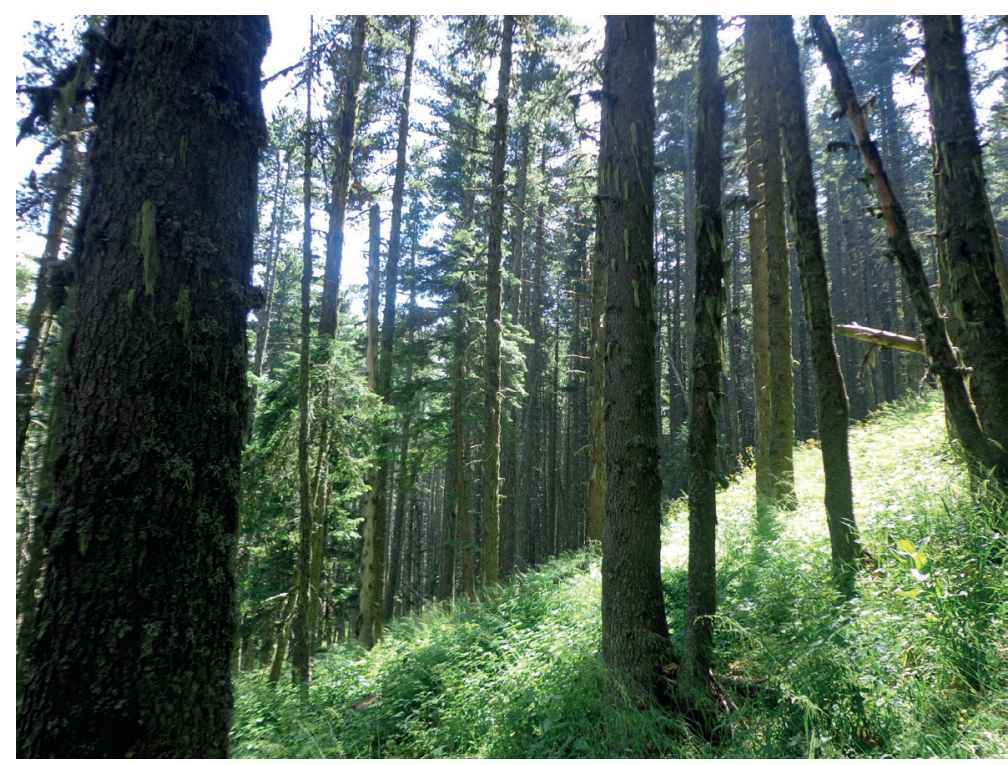

Figure 8: Stand of Macedonian pine on silicate parent material at Chemerikata - Nidže Mountain on silicate terrain. Macedonian pine manifests good structural characteristics. Photo: Dejan Mandžukovski.

Slika 8: Sestoj makedonskega bora na silikatni matični podlagi na lokaciji Chemerikata - planina Nidže na silikatu. Makedonski bor ima dobre strukturne značilnosti.

Foto: Dejan Mandžukovski. 

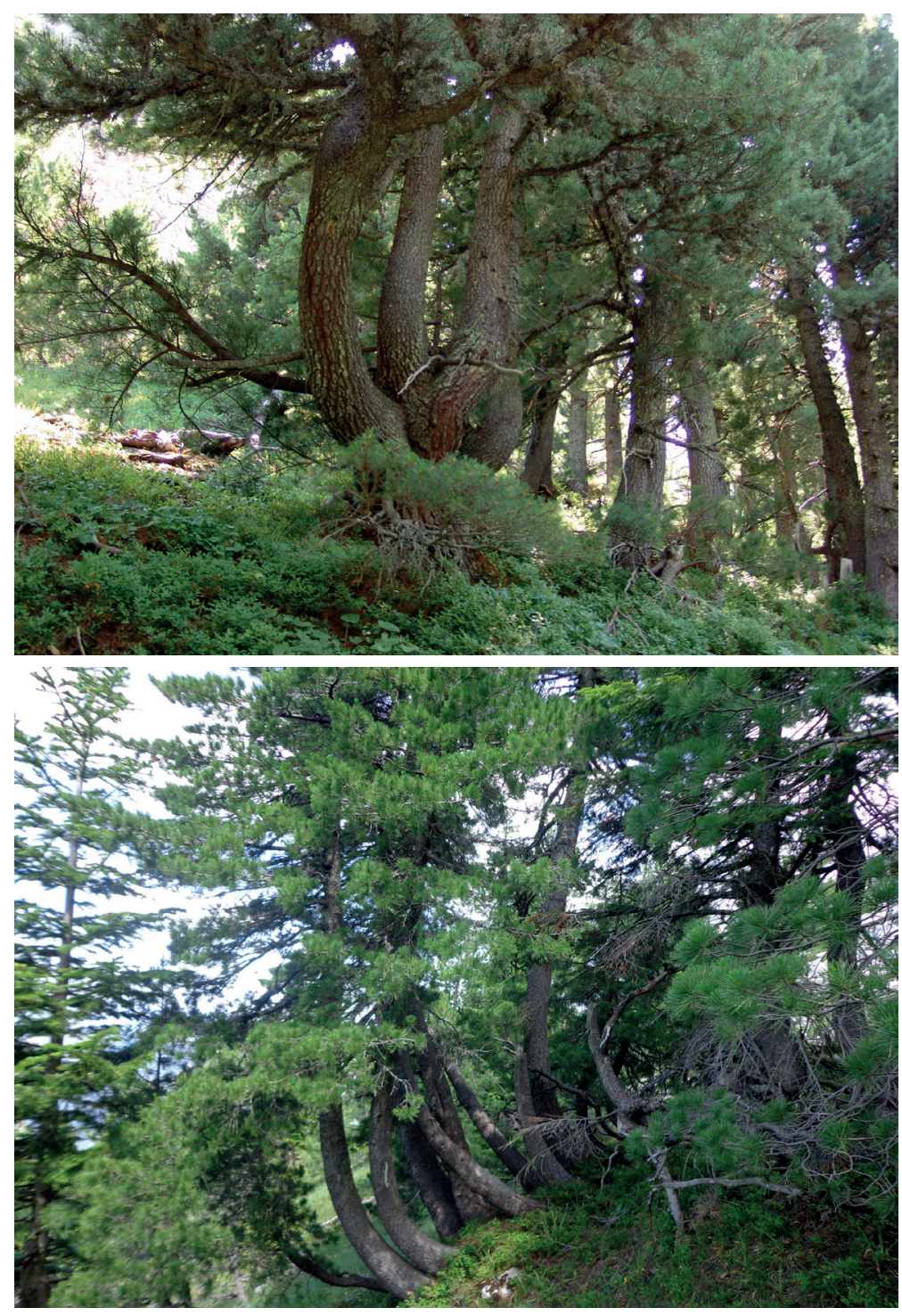

Figure 9: Stand of Macedonian pine on limestone at Plat - Shar Mountain. Some of the trees are multi-stemmed, formed by the mass fusion of single-stemmed trees of seed origin that formed and developed in dense groups and nests and then fused at the base of their trunks. Photo: Dejan Mandžukovski.

Slika 9: Sestoj makedonskega bora na apnencu na lokaciji Plat - planina Šara. Nekatera drevesa imajo več debel, ki so nastala z združevanjem iz posameznih dreves, ki so vzklila iz semen in se razvila v goste skupine ter se združila na bazi debel. Foto: Dejan Mandžukovski.

Figure 10: Stand of Macedonian pine on dolomite marble on Belo Grotlo - Nidže Mountain. Saber trees are the result of sliding snow. Photo: Dejan Mandžukovski.

Slika 10: Sestoj makedonskega bora na dolomitnem marmorju na lokaciji Belo Grotlo planina Nidže. Sabljasta rast je posledica plazečega snega. Foto: Dejan Mandžukovski.

\section{Conclusions}

The soil results show an evident increased presence of carbonates in the soil of screes of dolomite marble on Nidže Mountain, unlike those on Shar Mountain, which are formed on typical limestone. Macedonian pine at the locality Plat on Shar mountain has developed on sites on which carbonate is leached due to differences of the massifs, the regime of precipitation, geology, differences in soil properties in relation to the presence or absence of carbonates and $\mathrm{pH}$ values and other factors. On silicate terrain on Nidže Mountain, Macedonian pine forests have also developed on brown forest soils (cambisols) with a different floristic composition than on the other two parent materials. The ecological differences are reflected in the floristic composition of the communities.
Although the investigated vegetation has developed on a relatively small territory, the analysis showed significant diversity of stands and correlations between various parameters.

\section{Acknowledgements}

The authors are grateful to Blagoj Nikolov for his helpful cooperation with the English translation of the text and Bozin Trendafilov for preparing the map. The first author is also grateful to Andraž Čarni and Željko Škvorc for critical suggestions that improved the earlier version of the manuscript. 
Dejan Mandžukovski (D) https://orcid.org/0000-0002-6611-3396 Renata Ćušterevska (D) https://orcid.org/0000-0002-3849-6983 Rossen Tzonev (D) https://orcid.org/0000-0001-8112-1354 Marius Dimitrov (D) https://orcid.org/0000-0002-2632-7883

\section{References}

Andonoski, A. (1989). Dendrologija. Prosvetno Delo.

Alexandrov, A. H., \& Andonovski, V. (2011). EUFORGEN, Technical Guidelines for genetic conservation and use of Macedonian pine (Pinus peuce). Biodiversity International.

Braun-Blanquet, J. (1964). Pflanzensoziologie. Grundzüge der Vegetationskunde. Springer Verlag.

Bucalo, V., Stupar, V., \& Milanović, Đ. (2012). Characteristics and origin of the population of Macedonian pine (Pinus peuce Griseb.) at Jadovnik Mt. in Western Bosnia. Glasnik Šumarskog fakulteta Univerziteta u Banjoj Luci, 16, 7-29.

Chytrý, M., Tichý, L., Holt, J., \& Botta-Dukát, Z. (2002). Determination of diagnostic species with statistical fidelity measures. Journal of Vegetation Science, 13(1), 79-90, https://doi. org/10.1111/j.1654-103.2002.tb02025.x

Chytrý, M., \& Tichý, L. (2003). Diagnostic, constant and dominant species of vegetation classes and alliances of the Czech Republic: a statistical revision. Folia facultatis Scientiarum Naturalium Universitatis Masarykianae Brunensis, 108, 1-231.

Ćušterevska, R. (2015). Phytocoenological researches on the hilly and mountain pastures on the mountain Galicica [Unpublished doctoral dissertation]. Ss. Cyril and Methodius University in Skopje.

Džekov, S. (1988). Dendrologija. Univerzitet Kiril i Metodij.

Em, H. (1957). Megjusobni odnosi biljnih zajednica i zemljišta. Zemljište i biljka, 7, 125-132.

Ěm, H. (1965). Tipologija i ekologija na šumite. Zemjodelsko Šmarski Fakultet Skopje.

Em, H. (1967). Pregled na dendroflorata na Makedonija. Sojuz na inžineri i tehničari po šumarstvo i industrija za prerabotka na drvoto vo SR Makedonija.

Em, H., \& Džekov, S. (1969). Molikovata šuma na Pelister. In Zbornik na Simpozium za molikata (pp. 49-62).

Em, H. (1975). Oligotrofna bukova šuma so brukentalija i borovinki. Godišen Zbornik na Zemjodelsko - Šumarski Fakultet, Univerzitet vo Skopje, 27, 5-11.

Em, H. (1984). Na južnoj granici areala smrče, šuma smrče na Šarplanini u Makedoniji. Prilozi, Makedonska Akademija na Naukite $i$ Umetnostite, 5(1), 11-28.

Ellenberg, H., Weber, H.E., Düll, R., Wirth, V., Werner, W., \& Paulißen, D. (1992). Zeigerwerte von Pflanzen in Mittel-europa. Scripta Geobotanica, 18, 1-258.

European Council (1992). Council Directive 92/43/EEC of 21 May 1992 on the Conservation of natural habitats and of wild fauna and flora. Official Journal of the European Communities, 6(7), 7-50. https:// eur-lex.europa.eu/legal-content/EN/TXT/?uri=celex\%3A31992L0043
Euro+Med. (2006-). Euro+Med PlantBase - the information resource for Euro-Mediterranean plant diversity. Retrieved January 18, 2021, from http://ww2.bgbm.org/EuroPlusMed/00Rf.asp.

Farjon, A. (2017). Pinus peuce. The IUCN Red List of Threatened Species, e.T34193A95751594. https://dx.doi.org/10.2305/IUCN. UK.2017-2.RLTS.T34193A95751594.en

Filipovski, G. (Ed.) (1967). Metodika terenskog ispitivanja zemljišta i izrada pedoloških karata. JDPZ.

Filipovski, G., Rizovski R., \& Ristevski, P. (1996). The characteristics of the climate-vegetation-soil zones (regions) in the Republic of Macedonia. Macedonian Academy of Sciences and Arts.

Filipovski, G. (1984). Pedologija. Univerzitet Kiril i Metodij.

Filipovski, G. (1996). Soils of the Republic of Macedonia, Vol. II, Class of humus accumulative soils of $A-C$ and $A-R$ profile types. Macedonian Academy of Sciences and Arts.

Fukarek, P. (1970). Otkriće i današnja rasprostranjenost molike (Pinus peuce Gris.). In Zbornik na Simpozium za molikata (pp. 17-25).

Georgiev, G. (1970). Caracteristique des sols sous le Pinus Peuce en Bulgarie. In Zbornik na Simpozium za molikata (pp. 243-250).

Hennekens, S. M., \& Schaminée, J. H. J. (2001). TURBOVEG, comprehensive data base management system for Vegetation data. Journal of Vegetation Science, 12, 589-591.

Horvat, I. (1949). Nauka o bilinim zajednicama. Nakladni zavod Hrvatske.

Košanin, N. (1912). Šumski četinari na Šar Planini i Korabu. Glasnik geografskog društva Beograd, 1(1), 19-27.

Košanin, N. (1929). Die Koniferen Südserbiens. Glasnik botaničkog zavoda i bašte Universiteta u Beogradu, 1(2), 176-190.

Janssen, J., Rodwell, J., Garcia Criado, M., Gubbay, S., Haynes, T., Nieto, A., Sanders, N., Landucci, F., Loidi, J., Ssymank, A., Tahvanainen, T., Valderrabano, M., Acosta, A., Aronsson, M., Arts, G., Altorre, F., Bergmeier, E., Bijlsma, R.-J., Bioret, F., Bită-Nicolae, C., Biurrun, I., Calix, M., Capelo, J., Čarni, A., Chytry, M., Dengler, J., Dimopoulos, P., Essi, F., Gardfjeil, H., Gigante, D., Giusso del Gaido, G., Hajek, M., Jansen, F., Jansen, J., Kapfer, J., Mickolajczak, A., Molina, J. A., Molnar, Z., Paternoster, D., Piernik, A., Poulin, B., Renaux, B., Schaminee, J. H. J., Šumberova, K., Toivonen, H., Tonteri, T., Tsiripidis, I., Tzonev, R., \& Valachovič, M. (2016). European red list of habitats - Part 2. Terrestrial and freshwater habitats. Publications office. https://doi.org/10.2779/091372

Janković, M. (1960). Razmatranje o uzajamnim odnosima molike (Pinus peuce) i munike (Pinus heldreichii), kako i o njihovim ekološki osobinama, posebno u odnosu na geološku podlogu. Glasnik Botaničke bašte Univerziteta u Beogradu, 1(5), 141-180.

Janković, M. (1970). Some problems concerning the ecology, coenology distribution of the endemic-relic species Pinus peuce. In Zbornik na Simpozium za molikata (pp. 173-177).

Janković, M. (1962). Prilog poznavanju šuma endemičnih balkanskih borova munike (Pinus heldreichii) i molike (Pinus peuce) na severnoj strani Šarplanine i njenim metohijskim ograncima. Arhiv bioloških nauka, 14(3-4), 143-155.

JDPZ. (1966). Priručnik za ispitivanje zemljišta, knjiga I, Hemijske metode ispitivanja zemljišta. Jugoslovensko društvo za proučavanje zemljišta 
JDPZ. (1967). Priručnik za ispitivanje zemljista, knjiga IV, Metodika terenskog ispitivanja zemljišta i izrada pedoloskih karata. Jugoslovensko društvo za proučavanje zemljišta.

JDPZ. (1971). Priručnik za ispitivanje zemljišta, knjiga V, Metode istraživanja fizičkih svojstava zemljišta. Jugoslovensko društvo za proučavanje zemljišta.

Mandžukovski, D., Acevski, J., \& Jovanov T. (2009). Extension of the areal of molika pine (Pinus pence Grisb.) in the Republic of Macedonia. Šumarski pregled, 42, 55-162.

Mandžukovski, D., \& Acevski, J. (2013). Relic forest of Macedonian pine (Pinus peuce Grisb.) on calcareous parent material in Macedonia. In Book of abstracts EADSVE.

Mandžukovski, D., Andreevski, M., Ćušterevska, R., \& Acevski, J. (2015). Relationships between vegetation of Macedonian pine (Pinus peuce Grisb.) and different types of soils on which is developing. In Book of abstracts EADSVE.

Manojlović, S., Rajković, Z., Glincić, M., \& Šestić, S. (1969). Priručnik za sistematsku kontrolu plodnosti zemlijšta i upotrebu djubriva. Centar za unapređenje poljoprivredne proizvodnje SR Srbije \& Agrohemija.

Marchi, M., Castellanos-Acuna, D., Hamann, A., Wang, T., Ray, D., \& Menzel, A. (2020). ClimateEU, scale-free climate normals, historical time series, and future projections for Europe. Scientific Data, 7, 428. https://doi.org/10.1038/s41597-020-00763-0

Matevski, V., Čarni, A., Avramoski, O., Juvan, N., Kostadinovski, M., Košir, P., Marinšek, A., Paušič, A., \& Šilc, U. (2011). Forest vegetation of the Galičica mountain range in Macedonia. Založba ZRC SAZU.

Matevski, V., Čarni, A., Ćušterevska, R., Kostadinovski, M., \& Mucina, L. (2018). Syntaxonomy and biogeography of dry grasslands on calcareous substrates in the central and southern Balkans. Applied Vegetation Science, 21, 488-513. https://doi.org/10.1111/avsc.12374

Micevski, K. (1994). Visokoplaninskata vegetacija na planinata Bistra. Makedonska akademija na naukite i umetnostite.

McCune, B., \& Mefford, M. J. (1999). PC-ORD. Multivariate analysis of ecological data. Version 5. MjM Software Design.

Mucina, L. (1993). Nomenklatorische und syntaxonomische Definitionen, Konzepte und Methoden. In L., Mucina, G. Grabherr, \& T. Ellmauer, Die Pflanzengesellschaften Österreichs, Teil I. Anthropogene Vegetation (pp. 19-28). Gustav Fischer Verlag.

Nikolov, I., \& Dimitrov, M. (2015). Boreo-montane forest phytocoenoses in Central Stara Planina Mts. Forest Review, 46, 43-45.

Oksanen, J., Blanchet, F. G., Friendly, M., Kindt, R., Legendre, P., McGlinn, D.,Minchin, P. R., O'Hara, R. B., Simpson, G. L., Solymos, P. M., Stevens, H. H., Szoecs, E., \& Wagner, H. (2020). Vegancommunity ecology package, version 2.5-4. Retrieved July 08, 2021, from https://cran.r-project.org/web/packages/vegan/index.html

Orlov S. D., \& Grišina A. L. (1981). Praktikum po himii gumusa. Izdatelstvo Moskovskogo univerziteta.

Popovski, D., Vilarov, L., \& Spirovski, J. (1969). The soils of Baba Planina-Mt. and a part of the mountain Bigla and Crnovrshki rid. Annuaire- book of the Institute of Agronomy, 4, 5-41.

Radulović, S. (1939). Molika na planini Nidže-Kožuf. Šumarski list, 7 , 372-377.

Rizovski, R. (1978). Fitocenologija so osnovi na tipologija na šumite $i$ pasistata. Univerzitet S. Kiril I Metodij.
Rizovski, R. (2009). Vegetaciski podračja na Republika Makedonija. Makedonska enciklopedija kn. 1. Makedonska akademija na naukite i umetnostite.

Rivas-Martínez S., Penas, A., del Río, S., Herrero L., Sánchez-Mata, D., \& E. Díaz, T. (2004). Biogeographic Map of Europe. University of León.

Rozman, R. Dakskobler, I., \& Šilc, U. (2020). Phytosociological analysis of basophilic Scots pine forests in the Southeastern Alps. Hacquetia, 19(1), 23-80.

Stevanović, V., Jovanović, S., \& Janković, M. (1995). Prilog rasprostranjenju i ekologiji visokoplaninskih borova na Šarplanini. Glasnik Botaničkog zavoda i bašte Univerziteta u Beogradu, 28, 91-99.

Tichý, L. (2002). JUICE, software for vegetation classification. Journal for Vegetation Science, 13, 451-453.

Tichý, L., Chytrý, M., Hájek, M., Talbot, S. S., \& Botta-Dukát Z. (2010). OptimClass: using species-to-cluster fidelity to determine the optimal partition in classification of ecological communities. Journal for Vegetation Science, 21, 287-299. https://doi.org/10.1111/j.16541103.2009.01143.x

Tzonev, R. Dimitrov, M. Gussev, Ch., Vulchev, V., \& Nikolov I. (2018). Classification of the relict forest communities of Palla's Black Pine (Pinus nigra subsp. pallasiana) in Bulgaria. Hacquetia, 17(2), $125-161$.

Vasilevski, K., \& Acevski, J. (2004). Correlation between vegetation and soils of the island Golem Grad. Annual proceedings of Faculty of forestry, 9, 70-75.

Vilarov, L. (1965). Počvite pod šumi od molika (Pinus peuce) vo SR Makedonija. Godisen zbornik na Zemjodelsko - šumarskiot fakultet na Univerzitetot Skopje, šumarstvo, 17, 247-275. 


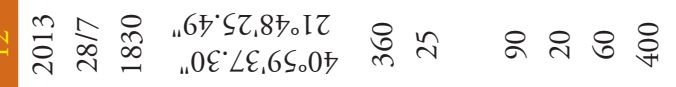

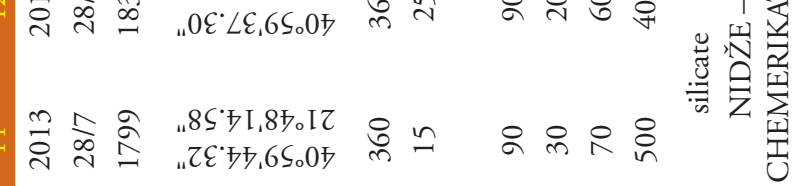

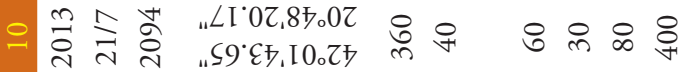

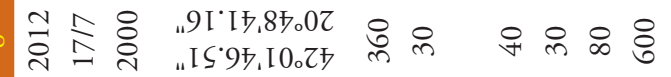

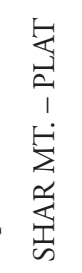

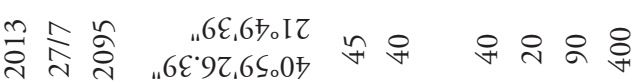

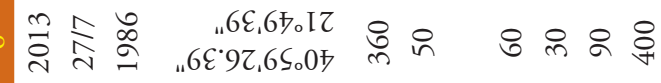

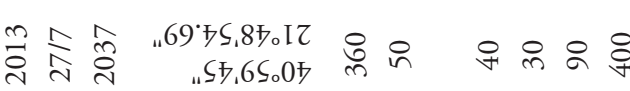

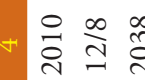

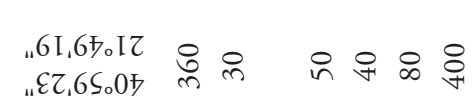

प⿺辶.

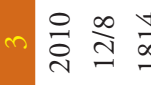

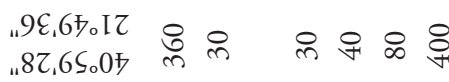
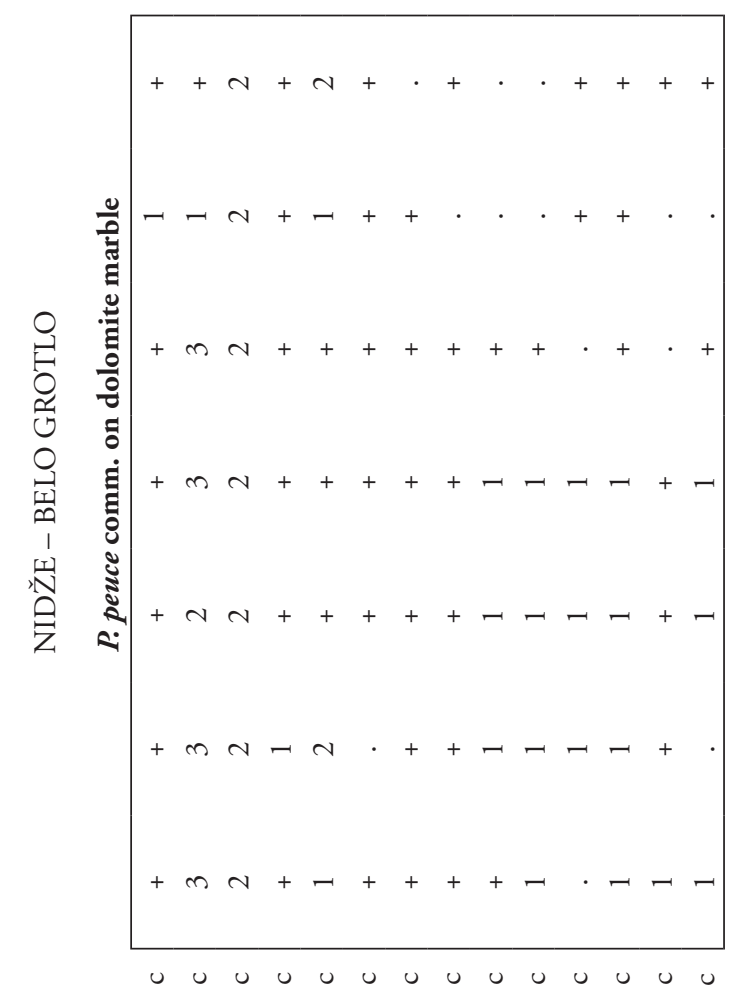

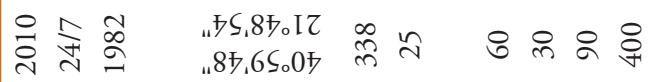

号学

\section{, 荙 西}




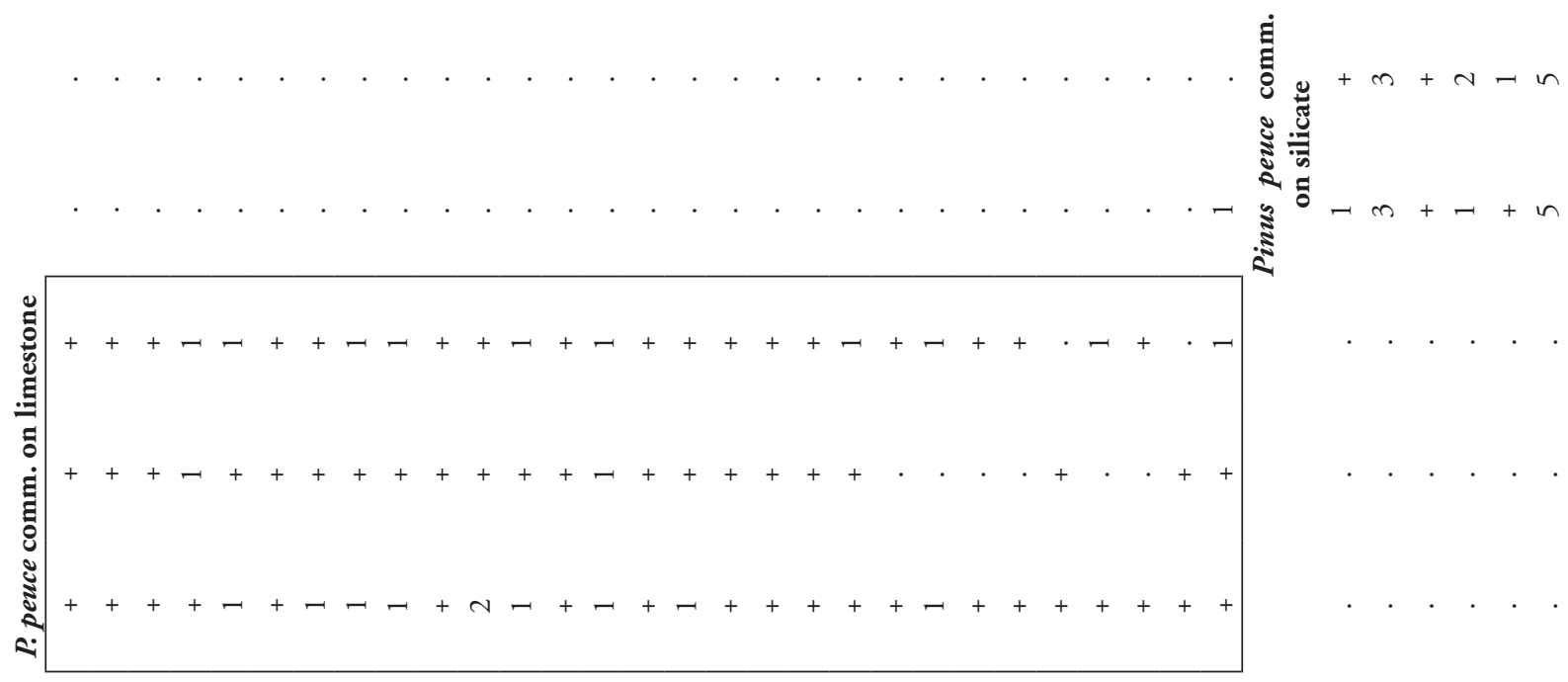

U 0 บ

$\begin{array}{lllllllll}0 & 0 & 0 & 0 & \approx\end{array}$
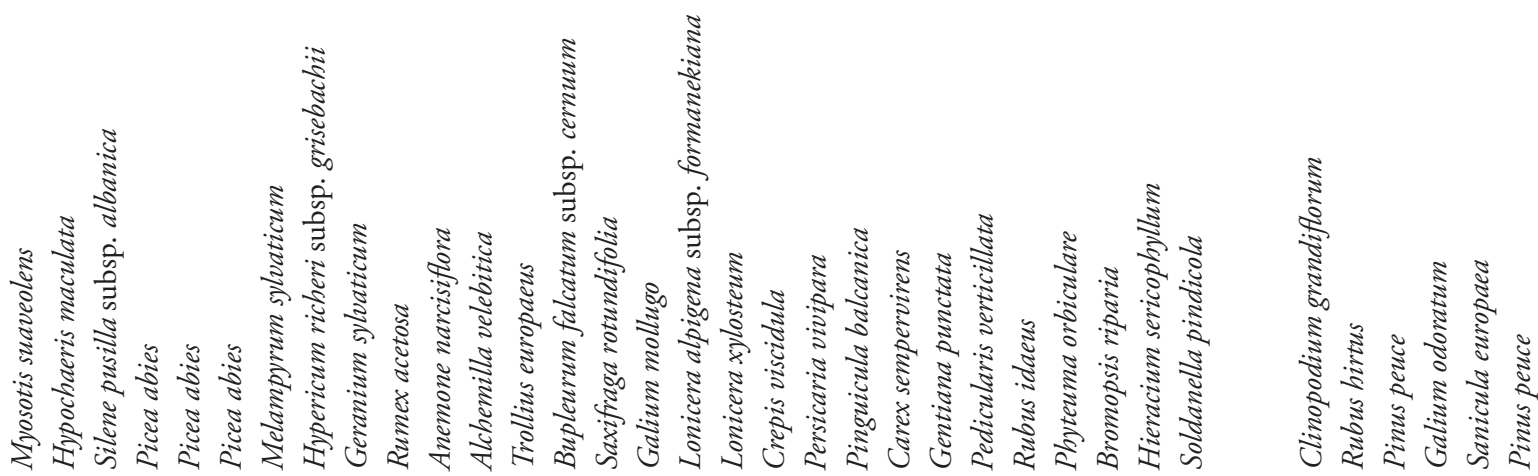

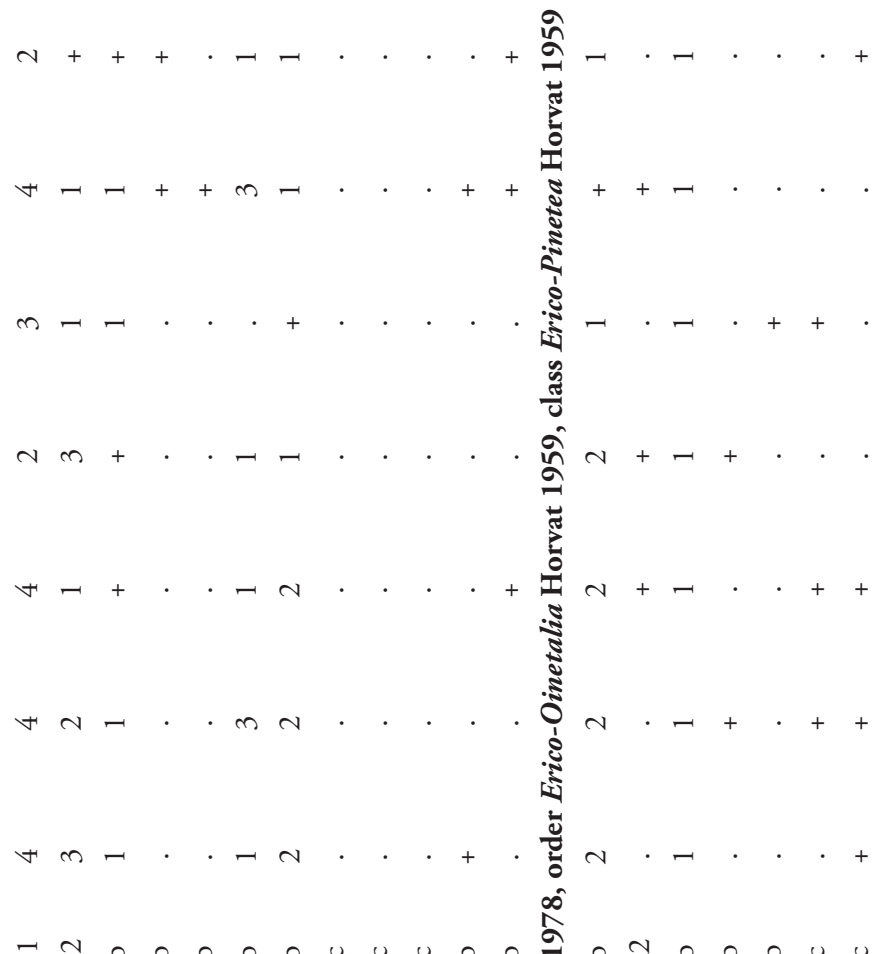

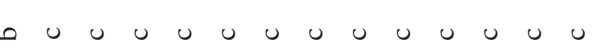
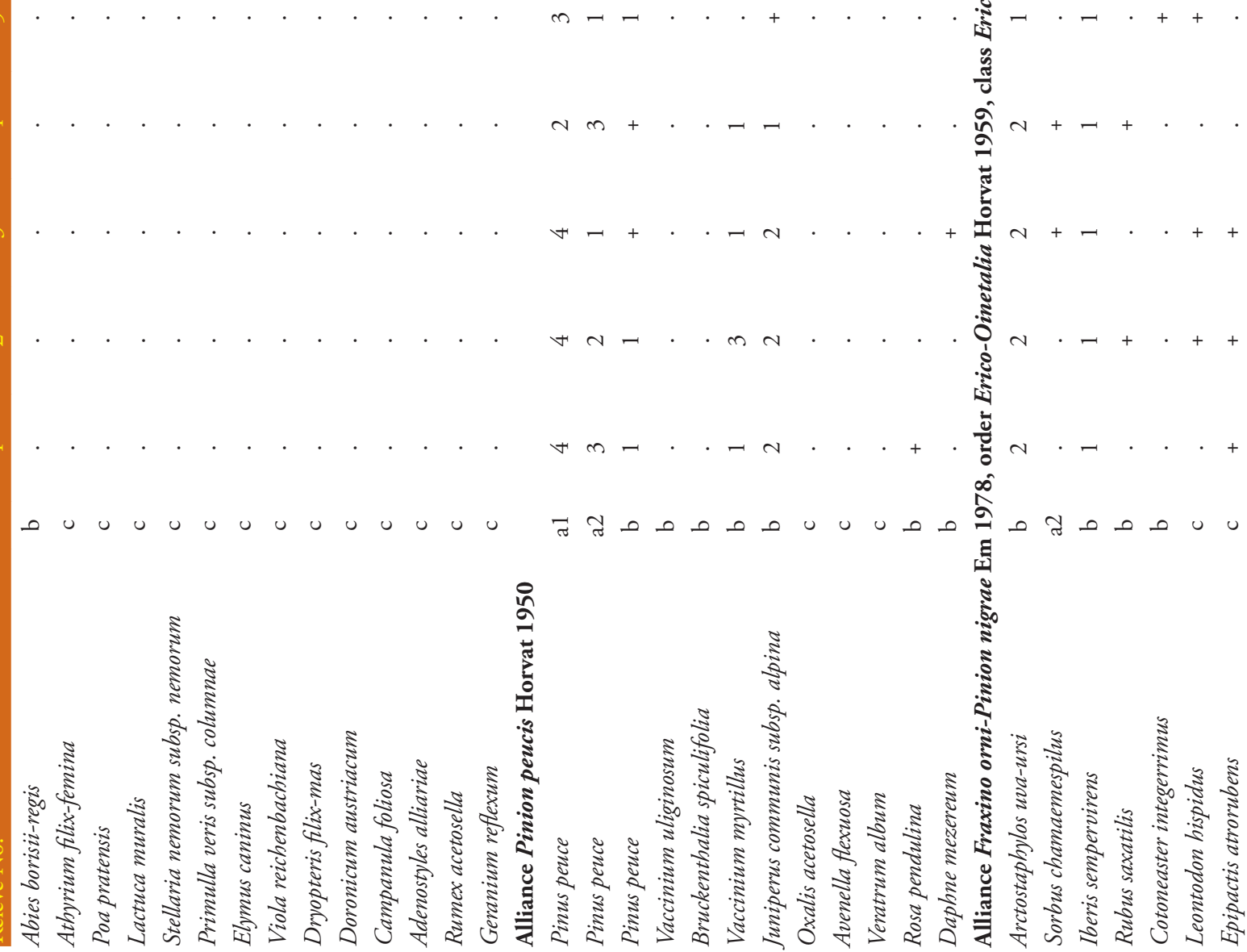


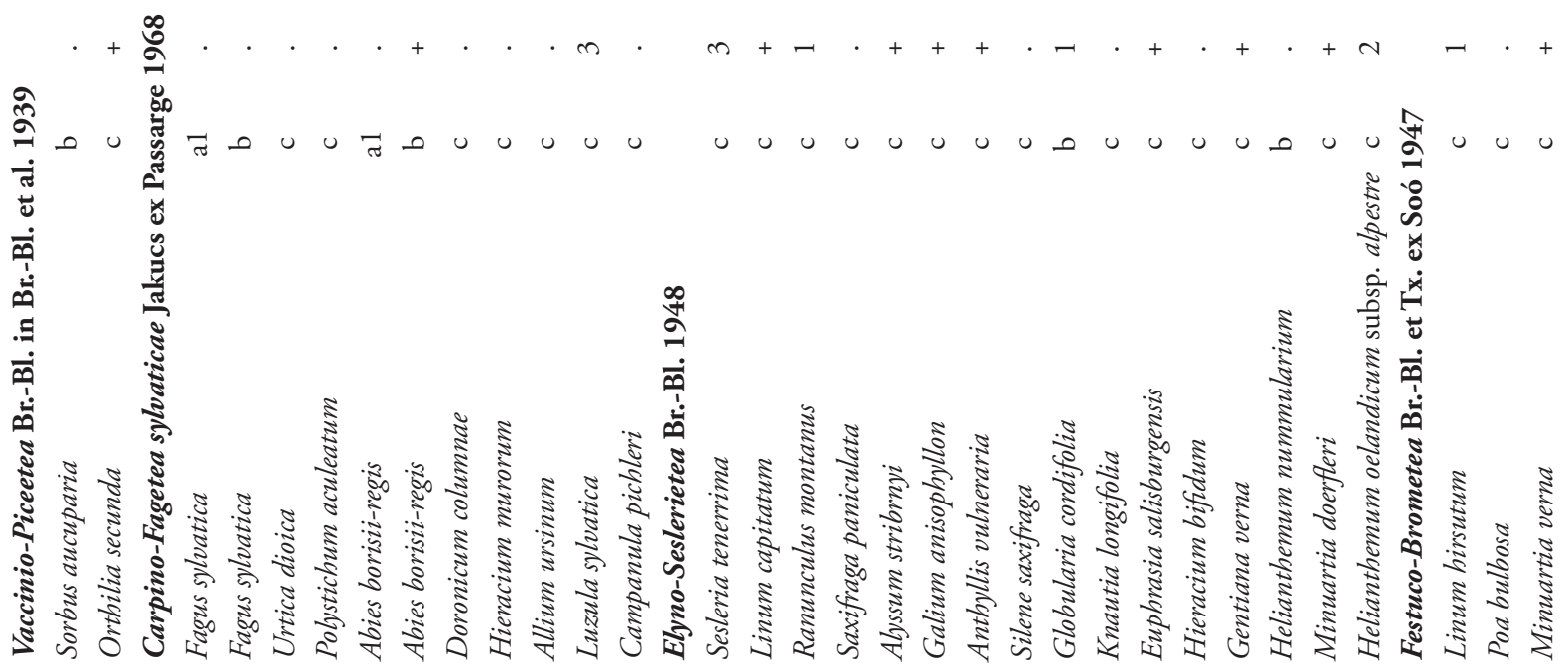




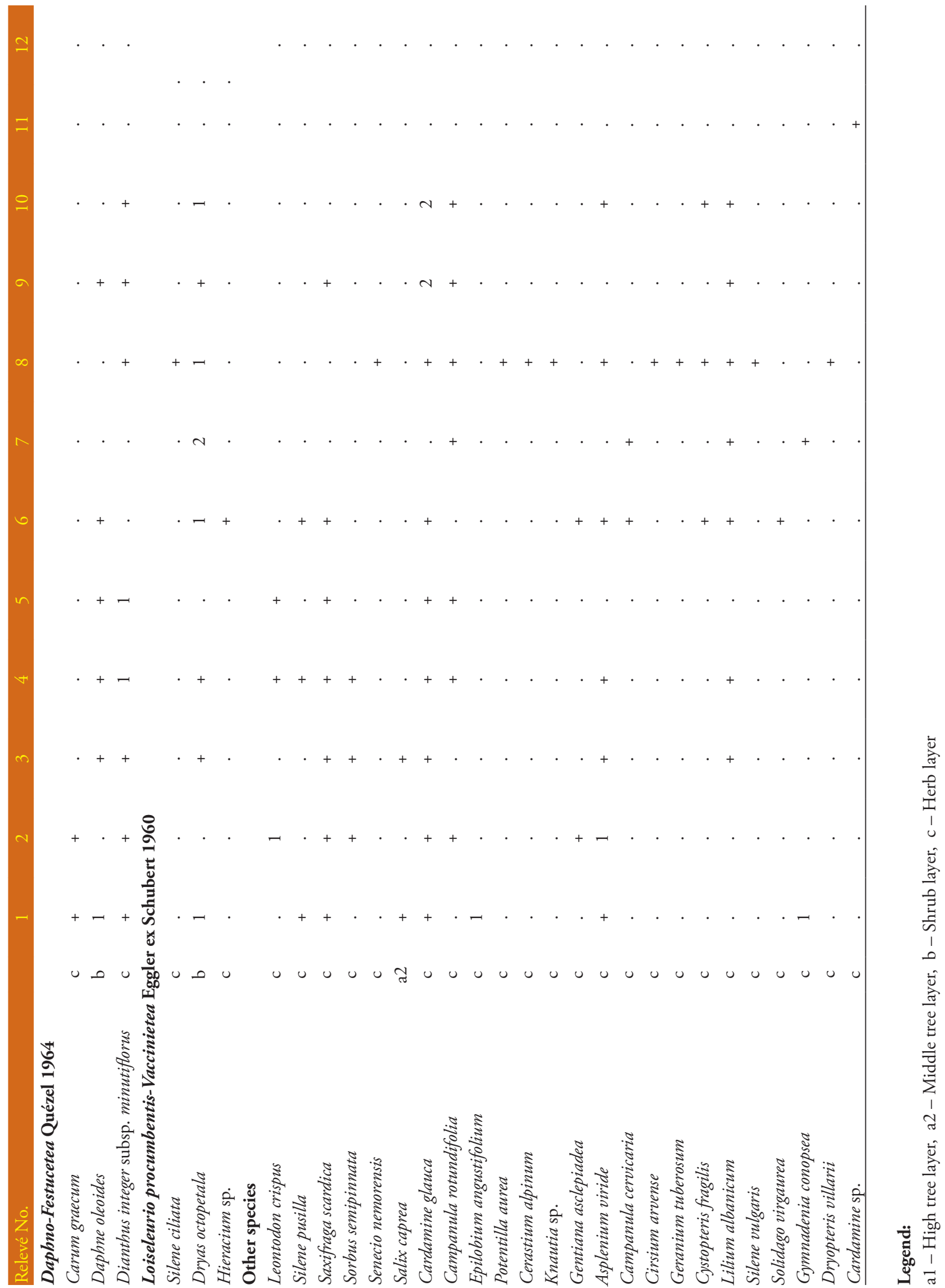

